\title{
La obra de arte en la época de su hiperreproducibilidad digital
}

The Work of Art in the time of its Digital Hiper-reproduction

Álvaro Cuadra

Phd. Universidad de La Sorbone. Director Académico del Programa de Doctorado en Educación y Cultura en América Latina de la Escuela Latinoamericana de Estudios de Postgrado y Políticas Públicas (ELAP) de la Universidad de Arte y Ciencias Sociales (ARCIS).

Acápite del Libro Los bigotes de monalisa, eBook. Santiago de Chile. 2012. VERSION COMPLETA 


\subsection{La iluminación profana}

La Nature est un temple où de vivant piliers Laissent parfois sortir de confuses paroles: L'Homme y passe à travers des forêts de symboles Qui l'observent avec des regards familiers

\section{Correspondances Charles Baudelaire}

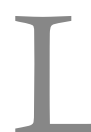

a obra de Walter Benjamin ha sido objeto de numerosos estudios y no pocos equívocos. La razón de esto la encontramos tanto en la pluralidad de fuentes que alimentaron su pensamiento como el modo singular de conjugarlas en su escritura. El escrito que ahora nos interesa, Das Kunstwerk im Zeitalter seiner technischen Reproduzierbarkeit, 1936, (La obra de arte en la era de su reproducibilidad técnica ${ }^{1}$, no está exento de esta singularidad que es, al mismo tiempo, su profunda riqueza.

Si bien debemos reconocer que en el complejo pensamiento de Benjamin hay elementos de teología, filología, teoría de la experiencia y de materialismo dialéctico, estas procedencias diversas se anudan en torno a un centro de gravedad, la teoría estética. $^{2}$ Esto supone ya una dificultad, pues en la época era fácil reconocer lo estético en la pintura, la poesía o la crítica literaria, pero no era tan evidente al hacerse cargo

\footnotetext{
${ }^{1}$ Benjamín, Walter. La obra de arte en la época de su reproductibilidad técnica in Discursos Interrumpidos I. Madrid. Taurus Ediciones. 1973: 17 - 59

${ }^{2}$ En el currículum que Benjamin redactó en 1925 con motivo de su tesis de habilitación declaraba: "la estética representa el centro de gravedad de mis intereses científicos" véase: Fernández Martorell, $C$. Walter Benjamin. Crónica de un pensador. Barcelona. Montesinos. 1992: 155
}

de "otros objetos": la obra de arte sin más, la fotografía o el cine. De acuerdo a nuestra hipótesis, lo que Benjamin llama tempranamente en la década de los treinta del siglo XX, teoría estética, es una nueva hermenéutica crítica cuya heurística no podría sino fundarse sobre conceptos totalmente nuevos y originales, por de pronto, ligar la noción de estética a su sentido etimológico, aiesthesis, en cuanto compromiso perceptual, es decir, corporal ${ }^{3}$. En último trámite, el esfuerzo de Benjamin configura uno de los primeros estudios serios en torno a los modos de significación. ${ }^{4}$

Es interesante destacar que el célebre escrito de Walter Benjamin en torno a "La obra de arte en la era de la reproductibilidad técnica" comienza con una cita de Paul Valéry del escrito titulado "La conquête de l'ubiquité" en la que nos advierte: "En todas las artes hay una parte física que no puede ser tratada como antaño que no puede sustraerse a la acometividad del co-

\footnotetext{
${ }^{3}$ Este punto de vista ha encontrado eco en las ciencias sociales y, hoy por hoy, son muchos los teóricos que han avanzado en esa dirección. Así, Giddens escribe: "La percepción nace de una continuidad espacial y temporal, organizada como tal de una manera activa por el que percibe. El principal punto de referencia no puede ser ni el sentido aislado ni el percipiente contemplativo, sino el cuerpo en sus empeños activos con los mundos material y social. Esquemas perceptuales son formatos con base neurológica por cuyo intermedio se elabora de continuo la temporalidad de una experiencia". Giddens, Anthony. La constitución de la sociedad. Buenos Aires. Amorrortu. 1995: 82

4 La hermenéutica benjaminiana procede analógicamente, mediante imágenes y alegorías, estableciendo "correspondances" para construir sutiles "figuras" que abren vastos territorios para su exploración: entre ellos, los modos de significación
} 
nocimiento y la fuerza modernos. Ni la materia, ni el espacio, ni el tiempo son desde hace veinte años, lo que han venido siendo desde siempre. Es preciso contar con que novedades tan grandes transformen toda la técnica de las artes y operen por tanto sobre la inventiva, llegando quizás hasta a modificar de una manera maravillosa la noción misma de arte" ${ }^{5}$ Podríamos aventurar que el escrito de Benjamin no es sino el desarrollo dialéctico de esta cita en la que se inspira nuestro autor. Debemos destacar que la cita constituye parte de su estrategia escritural, cuestión que ha sido reconocida por gran parte de sus exegetas. La cita es un dispositivo central en la escritura benjaminiana, al punto que se ha hablado del "método Benjamin" con reminiscencias claras del modo surrealista, como escribe Sarlo: "Con las citas, Benjamin tiene una relación original, poética $\mathrm{o}$, para decirlo más exactamente, que responde a un método de composición que hoy describiríamos con la noción de intertextualidad: las incorpora a su sistema de escritura, las corta y las repite, las mira desde distintos lados, las copia, varias veces, las parafrasea y las comenta, se adapta a ellas, las sigue como quien sigue la verdad de un texto literario; las olvida y las vuelve a copiar. Les hace rendir un sentido, exigiéndolas" 6

Notemos que Valéry reconoce una mutación radical en aquella parte física de la obra de arte, de ello se puede colegir que es precisamente aquí donde radica una nueva cuestión estética: en la materialidad significante de la obra. No sólo eso, además es capaz de advertir la tremenda transformación operada en el arte europeo desde 1890 hasta

\footnotetext{
${ }^{5}$ Valery, Paul. Pièces sur l'art. Paris. 1934 in Benjamin. Op. Cit. 17

6 Sarlo, Beatriz. Siete ensayos sobre Walter Benjamin.. Buenos Aires. Fondo de Cultura Económica. 20 reimp. 2006: 28

1930, en una cierta concepción espacio-temporal que podríamos resumir en el arte cinético y en la forma matricial del collage. ${ }^{7}$ Para decirlo en pocas palabras, Valéry anuncia una nueva fenomenología producida por los dispositivos tecno - expresivos de la modernidad estética. Benjamin será el encargado de crear la nueva teoría que dé cuenta de esta condición inédita de la obra de arte y lo hará apelando a la materialidad de la obra, por oposición a cualquier reclamo idealista en torno a la genialidad, el misterio, y a su eventual uso, en dicho contexto histórico, en un sentido fascista ${ }^{8}$

Reconocer en Benjamin a un pensador de raigambre materialista supone el riesgo de una concepción vulgar acerca de lo que esto significa ${ }^{9}$. Para hacerle justicia al autor, es imprescindible aclarar que el materialismo benjaminiano es, en primer lugar, una opción epistemológica, un conjunto de supuestos de investigación que adopta a lo largo de su tesis y cuyo principio axial es, por cierto, la reproducibilidad técnica. Con ello, Benjamin elabora una teoría sobre la condición de la obra de arte en el seno de las sociedades industriales, en su dimensión económico cultural, pero, principalmente,

\footnotetext{
${ }^{7}$ Bell, Daniel. Contradicciones culturales del capitalismo. Madrid. Alianza Universidad. 1977. Pp.- 117 y ss.

${ }^{8}$ Como afirma Hauser: "La atracción del fascismo sobre el enervado estrato literario, confundido por el vitalismo de Nietzsche y Bergson, consiste en su ilusión de valores absolutos, sólidos, incuestionables y en la esperanza de librarse de la responsabilidad que va unida a todo racionalismo e individualismo. Y del comunismo la intelectualidad se promete a sí misma el contacto directo con las amplias masas del pueblo y la redención de su propio aislamiento en la sociedad" Hauser, A. Historia social de la literatura y el arte. Barcelona. Editorial Labor. (Tomo III). 1980: 265

9 "Benjamin mantuvo siempre la tensión entre una perspectiva materialista y una dimensión utópica, moral, que debe capturar en el pasado la huella de la exploración ( 0 de la barbarie, para decirlo con sus palabras) para redimirla." Sarlo. Op. Cit. 44
} 
en los modos de significación, proponiendo en suma las coordenadas de un nuevo régimen de significación. Un segundo aspecto que debe ser esclarecido es el alcance de esta opción epistemológica materialista. Cuando Benjamin escribe sobre el surréalisme en 1929, reconoce en este movimiento una "experiencia" y un grito libertario comparable al de Bakunin, un distanciamiento de cualquier iluminación religiosa, no para caer en un mundo material sin horizontes ni altura sino para superarla: "Pero la verdadera superación creadora de la iluminación religiosa no está, desde luego, en los estupefacientes. Está en una iluminación profana de inspiración materialista, antropológica, de la que el Haschisch, el opio u otra droga no son más que escuela primaria" 10 En este sentido, el discurso de Benjamin muestra un parentesco con las tesis de André Breton y los surrealistas, en cuanto a entender el materialismo como una antropología filosófica asentada en la experiencia y la exploración. Si bien la palabra surréalisme se asocia de inmediato a la estética, debemos aclarar que se trata de una visión que, en rigor, excede con mucho el dominio artístico, en su sentido tradicional.

Cuando los surrealistas hablan de poesía, se refieren a una cierta actividad del espíritu, esto permite que sea posible un poeta que no haya escrito jamás un verso. En un panfleto de 1925 se lee: "Nada tenemos que ver con la literatura.... El surrealismo no es un medio de expresión nuevo o más fácil, ni tampoco una metafísica de la poesía. Es un medio de liberación total del espíritu y de todo lo que se le parece" ${ }^{11}$ Las metas de

10 Benjamin, W. El surrealismo. La última instantánea de la inteligencia europea in lluminaciones I. Madrid. Taurus Ediciones. reimpresión 1988:46

11 Nadeau. M. Historia del surrealismo. Barcelona. Editorial Ariel. 1975: 94

92 - Junio $2015 \bullet N^{\circ} 16$ la actividad surrealista pueden entenderse en dos sentidos que coexisten en Breton: por una parte se aspira a la redención social del hombre, pero al mismo tiempo, a su liberación moral en el más amplio sentido del término. "Transformar el mundo", según el imperativo revolucionario marxista, pero, al mismo tiempo, "Changer la vie" como reclamó Rimbaud, he ahí la verdadera mot d'ordre surrealista.

Los surrealistas emplearán varias técnicas para acceder a las profundidades de la psique. Entre ellas destacan tres: la escritura automática, el cadáver exquisito, el resumen de sueños. La escritura automática supone dejar fluir la pluma sin un control conciente explícito, se trata de "l'enregistrement incontrôlé des états d'âme, des images et des mots", ${ }^{12}$ y de este registro surge aleatoriamente lo insólito, lo inesperado. El cadáver exquisito, llamado así por aquel verso nacido de un trabajo colectivo "El cadáver exquisito beberá del vino nuevo", intenta yuxtaponer al azar palabras nacidas del encuentro de un grupo de personas en un momento dado; por último, las imágenes de nuestros sueños serán un material privilegiado para la exploración de lo inconsciente.

El pensamiento de Benjamin, puesto en perspectiva, es tremendamente original y contemporáneo en cuanto se aleja de un cierto funcionalismo marxista ${ }^{13}$ y se aven-

12 Lagarde et Michard. XXe. Siècle. Paris. Les Editions Bordas. 1969: 347

${ }^{13}$ Como Neumann y Kirchheimer desde la teoría política, Benjamin desarrolló, desde la perspectiva de una teoría de la cultura, concepciones y consideraciones que desbordaban el marco de referencia funcionalista de la teoría crítica...Los tres comprendieron enseguida que los contextos de vida social se integran mediante procesos de interacción social; las concepciones de este tipo desarrolladas por la teoría de la comunicación están anticipadas en la teoría del compromiso político elaborada por Neumann y Kirchheimer, así como en el concepto de experiencia social desarrollado por Benjamin en su sociología de la cultura. Véase: Honneth, Axel . Teoría crítica. La Teoría Social Hoy, por Anthony Giddens \& J. Tur- 
tura en aquello que llama "bildnerische Phantasie" (fantasía imaginal), una aproximación a la subjetividad de masas que bien merece ser revisada a más de medio siglo de distancia: "Como teórico de la cultura, el interés fundamental de Benjamín se refería a los cambios que el proceso de modernización capitalista ocasiona en las estructuras de interacción social, en las formas narrativas del intercambio de experiencias y en las condiciones espaciales de la comunicación, pues estos cambios determinan las condiciones sociales en que el pasado entra a formar parte de la "fantasía imaginal" de las masas y adquiere significados inmediatos en ella...Para Benjamín las condiciones socioeconómicas de una sociedad, las formas de producción e intercambio de mercancías sólo representan el material que desencadena las "fantasías imaginales" de los grupos sociales.... /de manera que/ los horizontes de orientación individuales siempre representan extractos de aquellos mundos específicos de los grupos que se configuran independientemente en procesos de interacción comunicativa, y que perviven en las fuerzas de la "fantasía imaginal". ${ }^{14}$ Así, entonces, el gesto benjaminiano radica en un nuevo modo de concebir los procesos histórico culturales, una hermenéutica sui generis cuyo parentesco con la poética surrealista no es casual. ${ }^{15}$

\section{2.- Reproducibilidad y modos de signi- ficación}

ner, Alianza Editorial, México,1991: 471

14 Op. Cit. $469-470$

15 El legado legítimo de las obras de Benjamin no implicaría arrancar sus intuiciones para insertarlas en el aparato histórico - cultural tradicional, ni tampoco "actualizarlas" con una pocas palabras nostálgicas...Por el contrario, consistiría en imitar su gesto revolucionario. BuckMorss. Op. Cit. 78
Leer la obra de Benjamin plantea un sinnúmero de dificultades, una de las cuales se encuentra en la novedad radical de su planteamiento. Esto se relaciona con los niveles de análisis que propone Benjamin frente a un régimen de significación naciente, como el que anunciaba el cine, por ejemplo, en contraste con la visión de Adorno y Horkheimer. Mientras éstos estructuraron un discurso cuyo foco era la dimensión económico cultural, en cuanto nuevos modos de producción y redes de distribución, así como condiciones objetivas para la recepción-consumo de bienes simbólicos en sociedades tardocapitalistas, Benjamin inaugura una reflexión sobre los "modos de significación" inherentes a la nueva economía cultural. Los modos de significación dan cuenta, justamente, de la "experiencia" cuyo fundamento no podría ser sino perceptual y cognitivo, esto es, la configuración del "sensorium", en una sociedad en que la tecnología y la industrialización son la mediaciones de cualquier percepción posible. La lectura de Benjamin que proponemos encuentra su asidero explícito en la hipótesis que anima todo su escrito: "Dentro de grandes espacios históricos de tiempo se modifican, junto con toda la existencia de las colectividades humanas, el modo y manera de su percepción sensorial" 16 . Por lo tanto la empresa del investigador no puede ser otra que "poner de manifiesto las transformaciones sociales que hallaron expresión en esos cambios de la sensibilidad" 17

Una mirada tal fue vista con desconfianza por sus pares, tanto por su oscuro método como por su particular modo de entender la cultura $^{18}$. Como refiere Martín - Barbero:

\footnotetext{
${ }^{16}$ Benjamin, Discursos. 24

${ }^{17}$ Ibidem

18 Implícita en las obras de Benjamin está una detallada y consistente teoría de la educación materialista que haría

$N^{o} 16 \bullet J u n i o 2015 \bullet \mathbf{9 3}$
} 
"Adorno y Habermas lo acusan de no dar cuenta de las mediaciones, de saltar de la economía a la literatura y de ésta a la política fragmentariamente. $\mathrm{Y}$ acusan de esto a Benjamin, que fue pionero en vislumbrar la mediación fundamental que permite pensar históricamente la relación de la transformación en las condiciones de producción con los cambios en el espacio de la cultura, esto es, las transformaciones del sensorium, de los modos de percepción, de la experiencia social" 19

Uno de los grandes aportes del pensamiento benjaminiano surge de un conjunto de categorías en torno a los nuevos modos de significación que modifican sustancialmente las prácticas sociales gracias a la irrupción de un potencial de reproducibilidad desconocido hasta entonces, esto es, tecnologías revolucionarias - la fotografía y el cine - que transforman las condiciones de posibilidad de la memoria y archivo. Como nos advierte Cadava: "...la fotografía - que Benjamin entiende como el primer medio verdaderamente revolucionario de reproducción - es un problema que no concierne sólo a la historiografía, a la historia del concepto de memoria, sino también a la historia general de la formación de los conceptos... Lo que se pone en juego aquí son los problemas de la memoria artificial y de las formas modernas de archivo, que hoy afectan todos los aspectos de nuestra relación con el mundo, con una velocidad y en una dimensión inédita en épocas anteriores" ${ }^{20} \mathrm{Si}$

posible esa rearticulación de la cultura, de ideología a arma revolucionaria. Esta teoría implicaba la transformación de las "mercancías" culturales en lo que él llamaba "imágenes dialécticas". Véase: Buck-Morss, Susan. Walter Benjamin, escritor revolucionario.10 Ed. Buenos Aires. Interzona Editora. 2005: 18

${ }^{19}$ Martín-Barbero, Jesús. De los medios a las mediaciones. Barcelona. Gustavo Gili. (20 edición). 1991: 56

${ }^{20}$ Cadava, Eduardo. Trazos de luz. Tesis sobre la foto-

$94 \cdot$ Junio $2015 \bullet N^{o} 16$ entendemos el aporte de Benjamin como un primer avance para esclarecer el vínculo entre reproducibilidad técnica y memoria, sea en cuanto sistema retencional terciario (registro), sea como memoria psíquica, podemos ponderar la originalidad y alcance del pensamiento benjaminiano.

Para nuestro autor, en coincidencia con Adorno aunque en una posición mucho más marginal de la Escuela de Frankfurt, la reproducción técnica de la obra de arte significaba la destrucción del modo aureático de existencia de la obra artística: " Como Adorno y Horkheimer, Benjamín pensaba al principio que el surgimiento de la industria de la cultura era un proceso de destrucción de la obra de arte autónoma en la medida en que los productos del trabajo artístico son reproducibles técnicamente, pierden el aura cúltica que previamente lo elevaba como una sagrada reliquia, por encima del profano mundo cotidiano del espectador....Sin embargo, las diferencias de opinión en el instituto no se desencadenaron por la identificación de estas tendencias de la evolución cultural, sino por la valoración de la conducta receptiva que engendran" ${ }^{21}$ En efecto, mientras Adorno veía en la reproducción técnica una "desestificación del arte", Benjamin creía ver la posibilidad de nuevas formas de percepción colectiva y con ello la expectativa de una politización del arte.

En América Latina, quien lleva esta lectura a sus últimas consecuencias es Martín-Barbero quien cree advertir en el pensamiento benjaminiano una "historia de la recepción", de tal modo que: "De lo que habla la muerte del aura en la obra de arte no es tanto de arte como de esa nueva percepción que, rompiendo la envoltura, el

grafía de la historia. Santiago. Palinodia. 2006: 19

${ }^{21}$ Honneth, Axel . Op. Cit. 467 
halo, el brillo de las cosas, y no sólo las de arte, por cercanas que estuvieran estaban siempre lejos, porque un modo de relación social les hacía sentirlas lejos. Ahora las masas, con ayuda de las técnicas, hasta las cosas más lejanas y más sagradas las sienten cerca. Y ese "sentir", esa experiencia, tiene un contenido de exigencias igualitarias que son la energía presente en la masa"22 Frente a una lectura como ésta, se impone cierta prudencia. Podríamos aventurar que el optimismo teórico de Martín-Barbero es una lectura datée característica de la década de los ochenta del siglo pasado que pretende hacer de la cultura el espacio de hegemonía y de lucha.

En principio, nada autoriza, de buenas a primeras, colegir de esta proximidad psíquica y social reclamada por las vanguardias y hecha experiencia cotidiana gracias a la irrupción creciente de ciertas tecnologías, la instauración de un contenido igualitario que, en una suprema expresión de optimismo teórico, redundaría en un redescubrimiento de la cultura popular y una reconfiguración de la cultura como espacio de hegemonía. No podemos olvidar que el igualitarismo se encuentra en la raíz misma de la mitología burguesa, cuya figura más contemporánea es el "consumidor" o "usuario", expresión última del "homo aequalis" como protagonista de toda suerte de populismos políticos y mediáticos. Asistimos más bien al fenómeno de la despolitización creciente de masas, en cuanto las sociedades de consumo son capaces de abolir el carácter de clase en la fantasía imaginal de las sociedades burguesas en el tardocapitalismo, mediante aquello que Barthes llamó "ex - nominación". ${ }^{23}$

\footnotetext{
22 Martín- Barbero. Op. Cit. 58

23 El proceso de ex - nominación ha abolido toda referencia al concepto de clase y en su lugar se establece

En América Latina, en la actualidad, está surgiendo un interesante replanteamiento de fondo sobre la cuestión de la defensa de lo popular, que durante décadas se mantuvo como un principio incuestionable exento de matices, Rodriguez Breijo se pregunta: "¿Tiene sentido defender algo que probablemente ya ni existe y que pierde su sentido en una sociedad donde las culturas campesinas y tradicionales ya no representan la parte mayoritaria de la cultura popular, y donde lo popular ya no es vivido, ni siquiera por los sujetos populares con una 'complacencia melancólica hacia las tradiciones'?. ¿Aferrarse a eso no será cegarse ante los cambios que han ido redefiniendo a estas tradiciones en las sociedades industriales y urbanas? ${ }^{24}$ Sea cual fuere la respuesta que pudiéramos ofrecer a estas interrogantes, lo cierto es que la hiperindustrialización de la cultura, rostro mediático de la globalización, representa un riesgo creciente en lo político y en lo cultural en nuestra región y reclama una nueva síntesis para nuevas respuestas, como nunca antes, un acto genuino de imaginación teórica. ${ }^{25}$

un énfasis en la forma de vida ; el concepto omniabarcante de la clase se debilita y cede espacio a otras formas de autodefinición, focalizados en rasgos culturales más específicos. La pluralidad de microdiscursos, es una realidad de dos caras; por una parte ha emancipado a las nuevas generaciones de una visión holística y unidimensional, que diluye los problemas cotidianos e inmediatos en la abstracción teórico - ideológica; pero, por otra parte, los microdiscursos pueden convertirse con facilidad en pseudorreligiones sectarias, ajenas a los problemas generales del ciudadano; más todavía, se puede llegar a microdiscursos intraducibles, exclusivos y excluyentes. Véase: Cuadra, A. De la ciudad letrada a la ciudad virtual. Santiago. Lom. 2003: 24

${ }^{24}$ Rodrigues Breijo, Vanessa. La televisión como un asunto de cultura in Televisión, pan nuestro de cada día. (Bisbal, coord.). Caracas. Alfadil Ediciones.2005: 107

\footnotetext{
${ }^{25}$ Lorenzo Vilches, citando a Hills ha expuesto descarnadamente el riesgo latinoamericano frente a la hiperindustrialización: "Es muy posible que en Latinoamérica se vuelva al pasado y que se verifique la afirmación de J. Hills de que 'all donde la empresa privada posee tanto la infraestructura do-
} 
En una primera aproximación, el ensayo de Benjamin comienza por reconocer que la reproducción técnica es de antigua data, nos recuerda que en el mundo griego, por ejemplo, tomó la modalidad de la fundición de bronces y el acuñamiento de monedas, lo mismo luego con la xilografía con respecto al dibujo y, desde luego, la imprenta como reproductibilidad técnica de la escritura. Asimismo, nos trae a la memoria el grabado en cobre, el aguafuerte y más tardíamente durante el siglo XIX la litografía. Sin embargo, la reproducción técnica entraña de manera ineluctable una carencia que no es otra que "la autenticidad", esto es, el "aquí y ahora" del original, una autenticidad en cuanto autoridad plena frente a la reproducción, incapaz de reproducir, precisamente, la autenticidad. Benjamin propone el término "aura" como síntesis de aquellas carencias: falta de autenticidad, carencia de testificación histórica: "Resumiendo todas estas carencias en el concepto de aura, podremos decir: en la época de la reproducción técnica de la obra de arte lo que se atrofia es el aura de ésta" 26

Esta hipótesis de trabajo se extiende más allá del arte para caracterizar una cultura entera en cuanto la reproducción técnica desvincula los objetos reproducidos del ámbito de la tradición. En la actualidad, la reproducibilidad ya no sería una mera posibilidad empírica sino un cambio en el sentido de la reproducción misma: "La reproducción técnica de la obra de arte", señala Benjamin," es algo nuevo que se impone en la historia intermitentemente, a empellones, muy distantes los unos de los otros,

méstica como los enlaces internacionales, los países en vias de desarrollo vuelvan a su anterior condición de colonias". Hills, J. Capitalism and the Information Age. Washington DC. Progress and Freedom Foundation. 1994 in Vilches, L. La migración digital. Barcelona. Gedisa. 2001: 28

${ }^{26}$ Benjamin. Discursos. 22

96 - Junio $2015 \bullet N^{o} 16$ pero con intensidad creciente". Ese "algo nuevo" al que se refiere aquí Benjamin entonces, no es meramente "la reproducción como una posibilidad empírica, un hecho que estuvo siempre presente, en mayor o menor medida, ya que las obras de arte siempre pudieron ser copiadas", sino como sugiere Weber, "un cambio estructural en el sentido de la reproducción misma...Lo que interesa a Benjamin y lo que considera históricamente 'nuevo' es el proceso por el cual las técnicas de reproducción influencias de manera creciente y, de hecho, determinan, la estructura misma de la obra de arte" 27.

La reproducción, efectivamente, no reconoce contexto o situación alguna y representa como dirá Benjamin "una conmoción de la tradición" 28 Esta descontextualización posibilitada por las técnicas de reproducción desconstruye la unicidad de la obra de arte en cuanto diluye el ensamblamiento de ésta con cualquier tradición. El objeto fuera de contexto ya no es susceptible de una "función ritual", sea éste mágico, religioso o secularizado. Como afirma nuestro autor: "...por primera vez en la historia universal, la reproductibilidad técnica emancipa a la obra artística de su existencia parasitaria en un ritual" 29

Las consecuencias de este nuevo estatus del arte se pueden sintetizar en dos aspectos. Primero, hay un cambio radical en la función misma del arte: expurgado de su fundamentación ritual se impone una praxis distinta, a saber: la praxis política. Segundo, en la obra artística decrece el "valor cultual" y se acrecienta el "valor exhibitivo" . En palabras del filósofo: "Con

\footnotetext{
${ }^{27}$ Cadava. Op. Cit. 96

${ }^{28}$ Benjamin. Op. Cit. 23

${ }^{29}$ Op. Cit. 27
} 
los diversos métodos de su reproducción técnica han crecido en grado tan fuerte las posibilidades de exhibición de la obra de arte, que el corrimiento cuantitativo entre sus dos polos se torna, como en los tiempos primitivos, en una modificación cualitativa de su naturaleza" 30

\section{3.- Shock, tiempo y flujos}

Resulta interesante el alcance que hace Benjamín al valor cultual inmanente a las fotografías de nuestros seres queridos, pues el retrato hace vibrar el aura en el rostro humano ${ }^{31}$. Atget, empero, retiene hacia 1900 las calles vacías de París, hipertrofiando el valor exhibitivo, anunciando lo que sería la revista ilustrada con sus notas al pie. La época de la reproductibilidad técnica le quita al arte su dimensión cultual y su autonomía. Como sostiene Berger: "Lo que han hecho los modernos medios de reproducción ha sido destruir la autoridad del arte y sacarlo - o mejor, sacar las imágenes que reproducen - de cualquier coto. Por vez primera en la historia, las imágenes artísticas son efímeras, ubicuas, carentes de corporeidad, accesibles, sin valor, libres. Nos rodean del mismo modo que nos rodea el lenguaje. Han entrado en la corriente principal de la vida sobre la que no tienen ningún poder por sí mismas"32

Durante la primera mitad del siglo XX, la tecnología audiovisual se desarrolló en torno al cine que, a su vez, es una ampliación y perfeccionamiento de la fotografía analógica y la fonografía, imponiendo la dimensión

\footnotetext{
${ }^{30}$ Op. Cit. 30

31 En la misma línea de pensamiento, Sontag escribe: "Las fotografías afirman la inocencia, la vulnerabilidad de vidas que se dirigen hacia su propia destrucción, y este lazo entre la fotografía y la muerte ronda todas las fotografías de personas". Véase: Sontag, Susan. Sobre la fotografía. Barcelona. Edhasa. 40 reimp. 1996: 80

${ }^{32}$ Berger, John et al. Modos de ver. Barcelona. Gustavo Gili.. (3o Ed): 1980 : 41
}

cinética mediante la secuencia de fotogramas. Así, el cine permitió por vez primera la narración con sonidos e imágenes en movimiento, mediante la proyección lumínica, adquiriendo un total protagonismo en la industrialización de la cultura. Benjamin pensaba que con el cine asistíamos a la mediación tecnológica de la experiencia, o si se quiere a una industrialización de la percepción. Como afirma Buck- Morss: "Benjamín sostenía que el siglo XIX había presenciado una crisis en la percepción como resultado de la industrialización. Esta crisis estaba caracterizada por la aceleración del tiempo, un cambio desde la época de los pasajes, cuando los coches de caballos todavía no toleran la competencia de los peatones, hasta la de los automóviles, cuando la velocidad de los medios de transporte...sobrepasa las necesidades. . . La industrialización de la percepción era también evidente en la fragmentación del espacio. La experiencia de la línea de montaje y de la multitud urbana era una experiencia de bombardeo de imágenes desconectadas y estímulos similares al shock" 33 Tratemos de examinar en qué consistiría ese shock y que implicancias podría tener en la cultura actual.

El cine, al igual que una melodía, se constituye en su duración. En este sentido, tales entidades 'son' en cuanto 'siendo'. En pocas palabras, estamos ante aquello que Husserl llamaba "objetos temporales": "Una película, como una melodía, es esencialmente un flujo: se constituye en su unidad como un transcurso. Este objeto temporal, en tanto que flujo, coincide con el flujo de la conciencia del que es el objeto - la conciencia del espectador" 34

Siguiendo la argumentación de Stiegler,

\footnotetext{
${ }^{33}$ Buck-Morss. Op. Cit. 69

${ }^{34}$ Stiegler, B. La técnica y el tiempo. Guipúzcoa. Editorial Hiru Hondarribia. 2004. T3:14
} 
habría que decir que el cine produce una doble coincidencia, por una parte conjuga pasado y realidad de modo fotofonográfico, creando un "efecto de realidad", y al mismo tiempo, hace coincidir el flujo temporal del filme con el flujo de la conciencia del espectador, produciendo una sincronización o adopción completa del tiempo de la película. En suma: “...la característica de los objetos temporales es que el transcurso de su flujo coincide 'punto por punto' con el transcurso del flujo de la conciencia del que son el objeto - lo que quiere decir que la conciencia del objeto adopta el tiempo de este objeto: su tiempo es el del objeto, proceso de adopción ,a partir del cual se hace posible el fenómeno de identificación típica del cine". ${ }^{35}$

El protagonismo del cine será opacado por la irrupción de la televisión durante la segunda mitad del siglo pasado. Si el cine permitió la sincronización de los flujos de conciencia con los flujos temporales inmanentes al filme, será la transmisión televisiva la que llevará la sincronización a su plenitud, pues aporta la trasmisión "en tiempo real" de "megaobjetos temporales". Bastará pensar en la gran final del Campeonato Mundial de Fútbol, Alemania 2006. Un público hipermasivo y disperso por todo el orbe, es capaz de captar el mismo objeto temporal, devenido por lo mismo megaobjeto, de manera simultánea e instantánea, es decir, "en directo". Como sentencia Stiegler: "Estos dos efectos propiamente televisivos transforman tanto la naturaleza del propio acontecimiento como la vida más íntima de los habitantes del territorio"36

En la hora presente, el potencial de reproducibilidad ha sido elevado exponencialmente debido a la irrupción de las

${ }^{35}$ Op. Cit. 47

${ }^{36}$ Op. Cit. 48

98 - Junio $2015 \bullet N^{o} 16$ llamadas nuevas tecnologías de la información y la comunicación. Esta suerte de "hiperreproducibilidad", como la denomina Stiegler, encuentra su fundamento en la diseminación de tecnologías masivas que instituyen nuevas prácticas sociales: “ La tecnología digital permite reproducir cualquier tipo de dato sin degradación de señal con unos medios técnicos que se convierten ellos mismos en bienes ordinarios de gran consumo: la reproducción digital se convierte en una práctica social intensa que alimenta las redes mundiales porque es simplemente la condición de la posibilidad del sistema mnemotécnico mundial" ${ }^{37} \mathrm{Si}$ a esto sumamos las posibilidades casi ilimitadas de simulaciones, manipulaciones y la interoperabilidad que permiten los sistemas de transmisión, habría que concluir con Stiegler: " La hiperreproducibilidad, que resulta de la generalización de las tecnologías numéricas, constituye al mismo tiempo una hiperindustrialización de la cultura, es decir, una integración industrial de todas las formas de actividades humanas en torno a las industrias de programas, encargadas de promover los "servicios" que forman la realidad económica específica de esta época hiperindustrial, en la que lo que antes era el hecho ya sea de servicios públicos, de iniciativas económicas independientes o el hecho de actividades domésticas es sistemáticamente invertido por 'el mercado"' 38

La reproducción técnica y la masificación de la cultura fue advertida por Paul Valéry, cuya cita pareciera estar hecha para caracterizar la televisión:" Igual que el agua, el gas y la corriente eléctrica vienen a nuestras casas, para servirnos, desde lejos y por medio de una manipulación casi im-

\footnotetext{
${ }^{37}$ Op. Cit .355

${ }^{38}$ Op. Cit. 356
} 
perceptible, así estamos también provistos de imágenes y de series de sonidos que acuden a un pequeño toque, casi a un signo, y que del mismo modo nos abandonan" 39 . Benjamin advierte que esta nueva forma de reproducción rompe con la presencia irrepetible e instala la presencia masiva, poniendo así lo reproducido fuera de su situación para ir al encuentro del destinatario. La televisión ha llevado a efecto la formulación universal propuesta por Benjamin en cuanto a que : "...la técnica reproductiva desvincula lo reproducido del ámbito de la tradición". ${ }^{40}$ No sólo eso, habría que repetir con nuestro teórico lo mismo que pensó respecto del cine: "La importancia social de éste no es imaginable incluso en su forma más positiva, y precisamente en ella, sin este otro lado suyo destructivo, catártico: la liquidación del valor de la tradición en la herencia cultural" ${ }^{41}$

La sincronización de los flujos temporales nos permite adoptar el tiempo del objeto, sin embargo, para que esto haya llegado a ser posible hay una suerte de training sensorial de masas, una apropiación de ciertos modos de significación que se encuentran inscritos como exigencias para un narratario y que se exteriorizan como principios formales de montaje. En este sentido, el shock es susceptible de ser entendido como una nuevo modo de experimentar la calendariedad y la cardinalidad. En una línea próxima, Cadava escribe: “ $\mathrm{E} 1$ advenimiento de la experiencia del shock como una fuerza elemental en la vida cotidiana a mediados del siglo XIX - sugiere Benjamin - , transforma toda la estructu-

\footnotetext{
${ }^{39}$ Valery, Paul. Pièces sur l'art, París, 1934 in Benjamin. Op. Cit. 20

${ }^{40}$ Benjamin. Op.Cit. 22

${ }^{41}$ Benjamin. Op. Cit. 23
}

ra de la existencia humana. En la medida en que Benjamin identifica este proceso de transformación con las tecnologías que han sometido "el sistema sensorial del hombre a un complejo training" y que incluyen la invención de los fósforos y del teléfono, la trasmisión técnica de información a través de periódicos y anuncios, y nuestro bombardeo en el tráfico y las multitudes, individualiza a la fotografía y al cine como medios que - en sus técnicas de corte rápido, múltiples ángulos de cámara, instantáneos - elevan la experiencia del shock, a un principio formal..." 42

En la era de la hiperreproducibilidad digital, la hiperindustrialización de la cultura representa el régimen de significación contemporáneo, cuya arista económico-cultural puede ser entendida como una hipermediatización. Los hipermedia administrados por grandes conglomerados de la industria de las comunicaciones son los encargados de producir, distribuir y programar el consumo de toda suerte de bienes simbólicos, desde casas editoriales multinacionales a canales televisivos de cobertura planetaria, pasando por la hiperindustria del entertainment y todos sus productos derivados. Ahora bien, como todo régimen de significación, el actual posee modos de significación bien definidos que podemos sintetizar bajo el concepto de "virtualización". Más allá de una presunta "alineación" de la vida y en un sentido más radical, la virtualización puede ser definida por su potencial genésico, por su capacidad de generar realidad, es decir:" La fundamental dimensión de la reproducción mediática de la realidad no reside ni en su carácter instrumental como extensión de los sentidos, ni en su capacidad manipuladora como factor condicionador de la conciencia, sino en su

${ }^{42}$ Cadava. Op. Cit. 178 
FACSO-UCE

valor ontológico como principio generador de realidad. A sus estímulos reaccionamos con mayor intensidad que frente a la realidad de la experiencia inmediata" 43

El shock es la imposibilidad de la memoria ante el flujo total de un presente que se expande. Disuelta toda distancia en el imperio del aquí y ahora, solo queda en la pantalla suspendido el still point, ya no como experiencia poética sino como sugirió Benjamin, mediante una recepción en la dispersión de la cual la experiencia cinematográfica fue pionera: "Comparemos el lienzo (pantalla) sobre el que se desarrolla la película con el lienzo en el que se encuentra una pintura. Este último invita a la contemplación; ante él podemos abandonarnos al fluir de nuestras asociaciones de ideas. Y en cambio no podremos hacerlo ante un plano cinematográfico. Apenas lo hemos registrado con los ojos y ya ha cambiado. No es posible fijarlo. Duhamel, que odia el cine y no ha entendido nada de su importancia, pero sí lo bastante de su estructura, anota esta circunstancia del modo siguiente: "Ya no puedo pensar 1o que quiero. Las imágenes movedizas sustituyen a mis pensamientos". De hecho, el curso de las asociaciones en la mente de quien contempla las imágenes queda enseguida interrumpido por el cambio de éstas. Y en ello consiste el efecto del choque del cine que, como cualquier otro, pretende ser captado gracias a una presencia de espíritu más intensa. Por virtud de su estructura técnica el cine ha liberado al efecto físico de choque del embalaje por así decirlo moral en que lo retuvo el dadaísmo"44

La hiperindustrialización cultural es capaz, precisamente, de fabricar el presente

\footnotetext{
${ }^{43}$ Subirats, E. Culturas virtuales. Madrid. Bibioteca Nueva. $2001: 95$

${ }^{44}$ Benjamin. Op. Cit. 51
}

$100 \bullet$ Junio $2015 \bullet N^{o} 16$ pleno mediante sus flujos audiovisuales "en vivo", que paradójicamente es también olvido. Como nos aclara Stiegler: "Al instaurar un presente permanente en el seno de flujos temporales donde se fabrica hora a hora y minuto a minuto un 'recién pasado' mundial, al ser todo ello elaborado por un dispositivo de selección y de retención en directo y en tiempo real sometido totalmente a los cálculos de la máquina informativa, el desarrollo de las industrias de la memoria, de la imaginación y de la información suscita el hecho y el sentimiento de un inmenso agujero de memoria, de una pérdida de relación con el pasado y de una desherencia mundial ahogada en un puré de informaciones de donde se borran los horizontes de espera que constituye el deseo" 45 Las redes hiperindustriales han hecho del shock, una experiencia cotidiana, trivial e hipermasiva, convirtiendo en realidad aquella "intuición" benjaminiana, un nuevo sensorium de masas que redunda en nuevo modo de significación cuya impronta, según hemos visto, no es otra que la experiencia generalizada de la compresión espacio - temporal.

Hagamos notar que, en efecto, Benjamin ofrece más intuiciones iluminadoras que un trabajo empírico consistente. Esto es así porque, recordemos, su pensamiento no pudo hacerse cargo del enorme potencial que suponía la nueva economía - cultural bajo la forma de una industrialización de la cultura, especialmente, del otro lado del Atlántico. Como apunta muy bien Renato Ortiz: "Cuando Benjamin escribe en los años 30, los intelectuales alemanes, a pesar de los traumas de la I Guerra Mundial y del advenimiento del nazismo, todavía son marcados por la idea de kultur, esto es, de un espacio autónomo que escapa a las imposiciones de la 'civilización' mate-

$\overline{45 \text { Stiegler. Op. Cit. } 115}$ 
rial y técnica. Al contrario de Adorno y de Horkheimer, Benjamin no conoce la industria cultural ni el autoritarismo del mercado; para los frankfurtianos, esa dimensión sólo puede ser incluida en sus preocupaciones cuando migran a Estados Unidos. Allí, la situación era enteramente otra: es el momento en que la publicidad, el cinematógrafo, la radio, y luego, rápidamente, la televisión, se vuelven medios potentes de legitimación y de difusión cultural". ${ }^{46}$ Este verdadero descubrimiento es el que realizará Adorno en sus investigaciones junto a Lazarfeld en el proyecto del Radio Research, encargado por la Rokefeller Foundation, en los años siguientes.

\section{4.- Estetización, politización, persona- lización}

Las actuales tecnologías digitales han permitido emancipar la imagen de cualquier referente, la nueva antropología de lo visual se funda en la autonomía de las imágenes. Esto es así porque estamos frente a constructos anópticos, no obstante reproducibles y que, de suyo, representan una fractura histórica respecto del problema de la reproducción. Se ha llegado a sostener que, en rigor, no estamos ante una tecnología de la reproducción sino más bien ante una de la producción: " La gran novedad cultural de la imagen digital radica en que no es una tecnología de la reproducción, sino de la producción, y mientras la imagen fotoquímica postulaba ' esto fue así', la imagen anóptica de la infografía afirma 'esto es así'. Su fractura histórica revolucionaria reside en que combina y hace compatibles la imaginación ilimitada del pintor, su libérrima invención subjetiva, con la perfección preformativa y autentificadora propia de la máquina. La infografía, por lo

\footnotetext{
${ }^{46}$ Ortiz, Renato. Modernidad y espacio. Benjamin en París. Bogotá. Editorial Norma. 2000: 124
}

tanto, automatiza el imaginario del artista con un gran poder de autentificación" 47

Si la fotografía, al decir de Benjamin, tecnología verdaderamente revolucionaria de la reproducción, despunta con el ideario socialista, la imagen digital irrumpe tras el ocaso de los socialismos reales. Es interesante notar cómo por la vía de la imagen digital se conjugan libertad imaginaria y autentificación formal, esta restitución de la autenticidad ya no reclama el mimetismo del cine o la fotografía sino que se erige como pura imaginación. La situación actual consistiría en que la obra de arte ya no reproduce nada (mimesis), en la actualidad la obra significa, mas solo existe en cuanto es susceptible de su hiperreproducibilidad , lo que se traduce en que las tecnologías digitales hacen posible la proximidad al mismo tiempo que la autenticidad ${ }^{48}$

El videoclip, y por extensión la imagen digital, se ha covertido en un fascinante objeto de estudio "postmoderno" en la medida que nos permite el análisis microscópico del flujo total, característica central de la hiperindustrialización de la cultura. Como escribe Steven Connor: "Resulta sorprendente que los teóricos de la postmodernidad se hayan ocupado de la televisión y el vídeo. Al igual que el cine (con el que la televisión coincide cada día más), la televisión y el vídeo son medios de comunicación cultural que emplean técnicas de reproducción tecnológicas. En un aspecto estructural superan a la narración moderna del artista individual que luchaba por trans-

\footnotetext{
${ }^{47}$ Gubern, Román. Del bisonte a la realidad virtual. Barcelona. Anagrama. 2006:147

${ }^{48}$ En una economía posindustrial en la que la información está reemplazando a la motricidad y a las energías tradicionales y las representaciones están sustituyendo a las cosas, la virtualidad de la imagen infográfica, autónoma, desmaterializada, fantasmagórica y arrepresentativa, supone su culminación congruente. Gubern Op. Cit. 149
} 
FACSO-UCE

formar un medio físico determinado. La unicidad, permanencia y trascendencia (el medio trasformado por la subjetividad del artista) en las artes reproductibles del cine y el vídeo parece haber dado lugar a una multiplicidad irrevocable, a cierta transitoriedad y anonimato...Otra forma de decirlo sería que el vídeo ejemplifica con particular intensidad la dicotomía postmoderna entre las estrategias interrumpidas de vanguardia y los procesos de absorción y neutralización de este tipo de estrategias" ${ }^{49}$ Se ha llegado a sostener, incluso, la hipótesis de una cierta periodización del capitalismo en relación a los saltos tecnológicos, cuyo objeto prototípico sería en la actualidad el vídeo, como explica Fredric Jameson: “ Si aceptamos la hipótesis de que se puede periodizar el capitalismo atendiendo a los saltos cuánticos o mutaciones tecnológicas con los que responde a sus más profundas crisis sistémicas, quizás quede un poco más claro por qué el vídeo, tan relacionado con la tecnología dominante del ordenador y de la información de la etapa tardía, o tercera, del capitalismo, tiene tantas probabilidades de erigirse en la forma artística por excelencia del capitalismo tardío"

El shock devenido con Eisenstein montaje-choque, es hoy una característica de los objetos audiovisuales más comunes y triviales, y alcanza su culmen en los llamados spots publicitarios y videoclips. Este fenómeno ha sido ejemplificado en el llamado "postcine". Como hace notar Beatriz Sarlo: "El postcine es un discurso de alto impacto, fundado en la velocidad con que una imagen reemplaza a la anterior. Cada nueva imagen a la que la precedió.

\footnotetext{
${ }^{49}$ Connor, Steven. Cultura postmoderna. Madrid. Akal. 1996: 115

50 Jameson, Fredric. Teoría de la postmodernidad. Madrid. Editorial Trotta. 1996: 106
}

Por eso las mejores obras del postcine son los cortos publicitarios y los videoclips". ${ }^{51}$ Los videoclips nacen, de hecho, como dispositivos publicitarios de la hiperindustria cultural, apoyando y promoviendo la producción discográfica. En pocos años, el espíritu experimentalista de los jóvenes realizadores formados en los hallazgos de las vanguardias estéticas (surrealismo, dadaísmo), dio origen a una serie de collages audiovisuales que destacan por su virtuosismo, conjugando libertad imaginativa y autentificación formal. Gubern escribe: "Los videoclips musicales depredaron y se apropiaron de los estilemas del cine de vanguardia clásico, de los experimentos soviéticos de montaje, de las transgresiones de los raccords de espacio y de tiempo, etc., por la buena razón de que no estaban sometidos a las rígidas reglas del relato novelesco y se limitaban a ilustrar una canción, que con frecuencia no relataba propiamente una historia, sino que exponía una sensaciones, más cercanas del impresionismo estético que de la prosa narrativa. Este descargo de obligaciones narrativas, liberados del imperativo del cronologismo y de la causalidad, permitió al videoclip musical adentrarse por las divagaciones experimentalista de carácter virtuoso" 52

Una de las acusaciones que se ha cursado contra la televisión radica, justamente, en su condición de flujo acelerado, incesante y urgente de imágenes. Este flujo total sería un obstáculo para el pensamiento: "Je disais en commençant que la televisión n'est pas trés favorable à l'expression de la pensée. J'établissais un lien, négatif, entre l'urgence et la pensée... Et un des problèmes majeurs que pose la télévision, cést la

\footnotetext{
${ }^{51}$ Sarlo. Op. Cit. 61

${ }^{52}$ Gubern, Román. El Eros electrónico. Madrid. Taurus. 2000:55
} 
question des rapports entre la pensée et la vitesse. Est-ce qu'on peut penser dans la vitesse? " ${ }^{3} \mathrm{Si}$ bien no es del caso discutir aquí este tópico de índole filosófica, tengamos presente esta relación entre velocidad y pensamiento en lo que respecta al shock de imágenes y sonidos que supone el flujo televisivo, pues esta cuestión está estrechamente ligada a la posibilidad misma de concebir un distanciamiento crítico.

Para Benjamin era claro que la reproductibilidad técnica de la obra de arte modificaba radicalmente la relación de la masa respecto del arte. Así, según escribe: "...cuanto más disminuye la importancia social de un arte, tanto más se disocian en el público la actitud crítica y la fruitiva" 54 De allí, entonces, que lo convencional se disfrute acríticamente mientras que lo innovador se critique con aspereza. Crítica y fruición coincidirían, según nuestro autor, en el cine. De manera análoga, se puede sostener que la hiperreproducibilidad digital modifica la relación de la obra artística con sus públicos ${ }^{55}$. Los archiflujos de programación televisiva anulan la posibilidad de una distancia crítica, privilegiando en sus públicos una actitud puramente fruitiva. Como sostiene Fredric Jameson: " Parece posible que, en una situación de flujo

\footnotetext{
${ }^{53}$ Bourdieu, Pierre. Sur la télévision. Paris. Liber. 1996 : 30

${ }^{54}$ Benjamin. Discursos 44

${ }^{55}$ Resulta cada vez más claro que los nuevos dispositivos tecnológicos y los procesos de virtualización que expanden y aceleran la semiósfera, desplazan la problemática de la imagen desde el ámbito de la reproducción al de la producción; así, más que la atrofia del modo aureático de existencia de lo auténtico, debe ocuparnos su presunta recuperación por la vía de la tecnogénesis y la videomorfización de imágenes digitales. Este punto resulta decisivo pues, siguiendo a Benjamin, habría que preguntarse si esta era inédita de producción digital de imágenes representa una nueva fundamentación en la función del arte y de la imagen misma; ya no derivada de un ritual secularizado como en la obra artística ni de la praxis política como en la era de la reproducción técnica. Cuadra, A. Op. Cit 130
}

total donde los contenidos de la pantalla manan sin cesar ante nosotros...lo que solía llamarse 'distancia crítica' se haya quedado obsoleto" 56

La hiperindustrialización de la cultura es el flujo total de imágenes y sonidos cuya característica es la búsqueda de umbrales de excitación cada vez mayores. No estamos ante la exhibición solemne de una gran obra, ni siquiera de una gran película capaz de dejar impresiones e imágenes en nuestra memoria equilibrando fruicion y crítica, más bien se trata de un flujo que aniquila las postimágenes con lo siempre nuevo, como en un videoclip. En este punto, se podría argumentar con Jameson, que hay una exclusión estructural de la memoria y la distancia crítica. ${ }^{57}$

El advenimiento de la hiperreproducibilidad digital no propugna ya ni una estetización de la política ni una politización del arte sino una 'personalización' del arte: "Si en los albores del siglo XX el fascismo respondió con un esteticismo de la vida política, el marxismo contestó con una politización del arte; hoy, en este momento inaugural del siglo XXI, el momento postmoderno pareciera apelar a una radical subjetivización / personalización del arte y la política, naturalizados como mercancías en una sociedad de consumo tardocapitalista. Ya el mismo Benjamin reconoció que el cine desplazaba el aura hacia la construcción artificial de una personality, el cul-

\footnotetext{
${ }^{56}$ Jameson. Op. Cit $101^{57}$ Los flujos hiperindustriales son "objetos temporales" en el sentido husserliano, es decir se comportan más como la música que como la pintura. En este sentido, habría que replantear el razonamiento que Benjamin atribuye a Leonardo en cuanto a que: "La pintura es superior a la música, porque no tiene que morir apenas se la llama a la vida, como el es caso infortunado de la música. Esta, que se volatiliza en cuanto surge, va a la zaga de la pintura, que con el uso del barniz se ha hecho eterna"

${ }^{57}$ Benjamin. Discursos. 45
} 
to a la estrella; que, sin embargo, no alcanzaba a ocultar su naturaleza mercantil La virtualización de las imágenes logra refinar al extremo esta impostura aureática, pues personaliza la generación de imágenes sin que por ello pierda su condición potencial de mercancía" Con todo, la hiperreproducibilidad digital no está exenta de los mismos riesgos políticos de largo plazo, pues como escribe Vilches: “...la información que normalmente viene exigida como un valor irrenunciable de la democracia y de los derechos humanos de los pueblos, representa también una forma de fascismo cotidiano. El mito de la información total puede convertirla en totalitaria". ${ }^{59}$

La obra de arte en la época de su hiperreproductibilidad digital se ha tornado en un mero significante, arte de superficie, que vaga por el laberinto del flujo total: Parodia inane y vacía a la que Jameson ha llamado "pastiche" 60 .

Los videoclips evidencian, a primera vis-

\footnotetext{
${ }^{58}$ Cuadra, A. Op. Cit. 13

${ }^{59}$ Vilches, L. La migración digital. Barcelona. Gedisa. 2001: 108

${ }^{60}$ Jameson, propone el concepto de pastiche como praxis estética postmoderna. El pastiche se apropia del espacio que ha dejado la noción de estilo. Dichos estilos de la modernidad "se transforman en códigos posmodernistas". El pastiche es imitación, pero a diferencia de la parodia, se trata de una: "repetición neutral....desligada del impulso satírico, desprovista de hilaridad y ajena a la convicción de que, junto a la lengua anormal que se toma prestada provisionalmente, subsiste aun una saludable normalidad lingüística." El pastiche es una parodia vacía. El pastiche, en tanto dispositivo de una cultura aniquila la referencialidad histórica; la serie sígnica organiza la realidad prescindiendo de la serie fáctica; los signos significan, pero no designan. Todos los estilos se dan cita en un aquí y ahora; de tal modo que, la historia deviene, en palabras de Jameson, historicismo o historia pop; una serie de estilos, ideas y estereotipos reunidos al azar suscitando la nostalgia propia de la mode rétro. Este nuevo lenguaje del pastiche representa "...la pérdida de nuestra posibilidad vital de experimentar la historia de un modo activo" Cuadra Op. Cit. 50
}

ta, su parentesco estético y formal con algunas obras de las vanguardias. Sin embargo, resulta evidente que a diferencia de un $\mathrm{Bu}-$ ñuel, por ejemplo, todo videoclip se inscribe en la lógica de la seducción inmanente a los bienes simbólicos que buscan posicionarse en el mercado más que en cualquier pretensión contestataria. Las vanguardias y el mercado resultan del todo congruentes en cuanto al experimentalismo y a la búsqueda constante de lo nuevo, aún cuando sus vectores de dirección son opuestos. Así, entonces, podemos afirmar que la lógica del mercado ha invertido el signo que inspiró a las vanguardias, pero ha instrumentalizado sus estilemas hasta la saciedad.

Estos principios se han extendido a la hiperindustria televisiva y cinematográfica en su conjunto, de manera tal que producciones recientes tan diversas como "Kill Bill", de Quentin Tarantino o "High School Musical" de Disney Channel se inscriben en la lógica del videoclip. En ambas producciones encontramos rasgos híbridos de distintos géneros audiovisuales, cuyo horizonte no puede ser otro que su éxito en términos comerciales, garantizada por una estructura narrativa elemental que rememora algunas tiras cómicas, pero plagada de efectos auditivos y visuales que llevan al "éxtasis sensual" a las nuevas generaciones de públicos hipermasivos formados en los cánones de una cultura internacional popular ${ }^{61}$. El perfil del "target" de la mayoría de estas producciones no podría ser otro que el "teenager" o el adulto teenager para quien la dosis precisa de violencia, melodrama, sexo y efectos especiales colma su fantasía imaginal.

$\mathrm{Si}$ bien el videoclip constituye uno de los

${ }^{61}$ Cfr. Ortiz, R. Cultura internacional popular in Mundialización y cultura. Buenos Aires. Alianza Editorial. 1997 : 145-198 
formatos de la televisión comercial ${ }^{62}$, y en algunos casos como MTV, el grueso de sus contenidos, debemos tener en cuenta que más allá de los soportes lo que las empresas comercializan es el concepto "música" o más ampliamente "entertainment". Por lo demás, un mismo producto asume diversos formatos para su comercialización, así la empresa Disney ofrece High School Musical como filme para televisión, DVD, $\mathrm{CD}$, álbum de láminas, presencia en la Web y una serie de programas paralelos a propósito de la producción. Los productos de "entertainment" adquieren la condición de "eventos multimediales" que asegura una mayor presencia en el mercado, tanto desde el punto de vista de su distribución mundial como de duración en el tiempo. El despliegue de estos productos en un mercado global débilmente regulado genera, no obstante, utilidades impensadas hace dos décadas. La modernidad, devenida hipermodernidad de flujos convierte el capital en imagen e información, esto es, en lenguaje.

\section{5.- Modernidad, patrimonio e hiperre- producibilidad}

Tal como sostenemos, la hiperindustrialización de la cultura entraña la hiperreproducibilidad como práctica social generalizada. Este fenómeno posee una arista política que va creciendo en importancia y que se relaciona con la noción de "propiedad" o, como suele decirse, el "copy right".

\footnotetext{
62 En relación a los flujos de la televisión comercial, se imponen algunos límites dignos de ser considerados. Como señala Tablante: "Si bien es cierto que la televisión es un flujo de contenidos programáticos, también es cierto que éstos tienen unos límites relativos a su intención, a su duración y a su estética. En este sentido, la televisión funcionaría como un atomizador de programas particulares que tienen un 'espacio' específico dentro de la programación del canal". Véase: Tablante, Leopoldo. La televisión frente al receptor: intimidades de una realidad representada"in Televisión, pan nuestro de cada día. (Bisbal, coord.). Caracas. Alfadil Ediciones.2005: 120
}

Si consideramos que la mayor parte de la producción hiperindustrial proviene de zonas de alto desarrollo, sus costes resultan muy elevados en las zonas pobres del planeta, surgiendo así la copia "ilegal" o "piratería": "Es una amenaza mayor a la del terrorismo y está transformando aceleradamente el mundo". Así define Moisés Naím, director de la prestigiosa revista estadounidense "Foreign Policy", el mercado del tráfico ilícito, eje de su libro, llamado justamente "Ilícito",... El mercado de las falsificaciones, que hace unos 15 años era muy pequeño, hoy mueve entre US\$ 400 mil y US\$ 600 mil millones. 'Sólo en películas copiadas es de US\$ 3 mil millones', afirma Naím. En cuanto al lavado de dinero, según el Fondo Monetario Internacional (FMI), hoy representa más del 10\% del tamaño de la economía mundial....' Lo que ocurre en Chile, sucede en Washington, Milán y Nueva York. Lo normal en una ciudad del mundo es que al caminar por las calles te encuentres con vendedores ambulantes que comercian productos falsificados', afirma Naím. Y el efecto de esto es que las ideas tradicionales de protección de propiedad intelectual están siendo socavadas. 'El mundo ha funcionado bajo la premisa de que hay que proteger la propiedad intelectual y que esa garantía la da el gobierno. Esa idea ya no es válida'. Naím señala que quienes tienen una creación ya no pueden contar con los gobiernos para que les protejan su propiedad: 'Ya no hay que llamar a un abogado para que dé una patente, eso es una ilusión. Es mejor llamar a un ingeniero o científico que busque la manera de hacer más difícil el copiado' ${ }^{63}$

El control tecnocientífico de la hiperreproducibilidad redunda en una verdadera expropiación o depredación de todo patri-

${ }^{63}$ Tráfico ilícito, el negocio más global y lucrativo del mundo. Santiago. El Mercurio. 18 de febrero. 2007 
monio cultural y genético de aquellos más débiles. De allí que la copia no autorizada impugna el orden de la "nueva economía" $\mathrm{y}$, en este sentido, es tenido como acto de legítima defensa de los sectores marginados de la corriente principal del capitalismo global. La cuestión del "derecho a la reproducibilidad" está en el centro del debate contemporáneo y determinará, sin duda, la rapidez de la expansión y penetración de la hiperindustrialización de la cultura, así como las modalidades de resistencia de las diversas comunidades y naciones. Como escribe Bernard Stiegler: "La toma de control sistemático de los patrimonios significa que a partir de ahora /la hiperreproducibilidad digital/ se aplica a todos los dominios de la vida humana, que constituyen otros tantos nuevos mercados para continuar con el desarrollo tecno-industrial, lo que se denomina a veces 'la nueva economía', donde la cuestión se convierte evidentemente en la de saber quién detenta el derecho de reproducir, y con él, de definir los modelos de los procesos de reproducción como los modelos que hay que reproducir. La cuestión ${ }_{64}$ es: ¿Quién selecciona y con qué criterios?"

Uno de los centros de producción de la hiperindustria cultural se encuentra, qué duda cabe, en Hollywood, lo que constituye un hecho político de primer orden: "El poder estadounidense, mucho antes que su moneda o su ejército, es la forja de imágenes holliwoodienses, es la capacidad de producir unos símbolos nuevos, unos modelos de vida y unos programas de conducta por medio del dominio de las industrias de programas a nivel mundial" 65 $\mathrm{Si}$ es cierto que la modernidad se materializa en la técnica, habría que agregar que dicha materialización ha tenido lugar en

\footnotetext{
${ }^{64}$ Stiegler. Op. Cit 368

${ }^{65}$ Op. Cit. 171
}

Norteamérica, lo cual muestra dos rostros, promesa y amenaza: "Estados Unidos sigue pareciendo hoy el país donde se realiza el devenir. Incluso sí, ahora, este devenir le parece a veces infernal y monstruoso al resto de mundo sin devenir. Tal es también quizá, la novedad. En el contexto de la globalización convertida en efectiva, teniendo en cuenta en particular la integración digital de las tecnologías de información y de comunicación, Estados Unidos parece constituir la única potencia verdaderamente mundial - pero también, y cada vez más, una potencia intrínsecamente imperial, dominadora y amenazante". ${ }^{66}$

En este siglo que comienza, asistimos a la apropiación de las mnenmotecnologías y de los sistemas retencionales por la vía de la alta tecnología digital, esto es: la apropiación de la memoria y del imaginario a escala mundial. En el ámbito latinoamericano, la hiperindustrialización de la cultura representaría un "décalage" y una clara amenaza a todo aquello que ha constituido su propia cultura y sus identidades profundas $^{67}$. Su defensa, no obstante, ha estado

\section{${ }^{66}$ Op. Cit. 185}

${ }^{67}$ Martin-Barbero plantea una hipótesis afín cuando
escribe: "Se trata de la no contemporaneidad entre los pro-
ductos culturales que se consumen y el 'lugar', el espacio
social y cultural, desde el que esos productos son consumi-
dos, mirados o leídos por las mayorias en América Latina".
En toda su radicalidad, la tesis de Martin-Barbero adquiere
el carácter de una verdadera esquizofrenia: "...en América
Latina la imposición acelerada de esas tecnologías ahonda
el proceso de esquizofrenia entre la máscara de moderni-
zación, que la presión de las transnacionales realiza, y las
posibilidades reales de apropiación e identificación cultural".
Examinemos de cerca esta hipótesis de trabajo. Podemos
advertir que la afirmación misma apunta a dos órdenes de
cuestiones que se nos presentan ligadas, por una parte la
"imposición de tecnologías" y, por otra, las "posibilidades rea-
les de apropiación". Desde nuestro punto de vista, la primera
se inscribe en una configuración económico-cultural en que
las nuevas tecnologías son el fruto de la expansión de la ofer-
ta a nuevos mercados, así nos convertimos en terminales de
consumo de una serie de productos creados en los labora-

${ }^{67}$ Martin-Barbero plantea una hipótesis afín cuando escribe: "Se trata de la no contemporaneidad entre los productos culturales que se consumen y el 'lugar', el espacio . En toda su radicalidad, la tesis de Martin-Barbero adquiere el carácter de una verdadera esquizofrenia: "...en América Latina la imposición acelerada de esas tecnologías ahonda idrenia entre la máscara de moderniposibilidad Examinemos de cerca esta hipótesis de trabajo. Podemos advertir que la afirmación misma apunta a dos órdenes de ve se nos presentan ligadas, por una parte la se inscribe en una configuración económico-cultural en que las nuevas tecnologias son el fruto de la expansión de la oferconsumo de una serie de productos creados en los labora- 
plagada de una serie de malentendidos e ingenuidades.

Las políticas culturales de los gobiernos de la región, más ocupadas de preservar el patrimonio monumental y el folcklorismo con propósitos turísticos, no advierten los riesgos implícitos en sus políticas de adopción de nuevas tecnologías cuya última frontera es, hoy por hoy, la televisión digital de alta definición. Un buen ejemplo respecto a ciertas paradojas políticas en "defensa de lo propio" nos la ofrece Nestor García Canclini a propósito de Tijuana, cuyo Ayuntamiento registró el "buen nombre de la ciudad" para protegerlo de su uso mediático publicitario: "La pretensión de controlar el uso del patrimonio simbólico de una ciudad fronteriza, apenas a dos horas de Hollywood, se ha vuelto aún más extravagante en esta época globalizada, en que gran parte del patrimonio se forma y difunde más allá del territorio local, en las redes invisibles de los medios. Es una consecuencia paródica de plantear la interculturalidad como oposición identitaria en vez de analizarla de acuerdo con la estructura de las interacciones culturales" 68

torios de grandes corporaciones, productos, por cierto, que no son sólo materiales (hardwares) sino muy especialmente inmateriales (softwares). La segunda afirmación contenida en la hipótesis dice relación con los modos de apropiación de dichas tecnologías, es decir, remite a modos de significación. Podríamos reformular la hipótesis de Martin-Barbero en los siguientes términos: América Latina vive una clara asimetría en su régimen de significación, por cuanto su economía cultural está fuertemente disociada de los modos de significación. Advertimos en nuestro autor un énfasis importante en torno a lo popular como principio identitario, clave de resistencia y mestizaje. Surge, empero, la sospecha de que ya no resulta tan evidente afirmar una cultura popular en medio de sociedades sometidas a acelerados procesos de hiperindustrialización de la cultura. Martín-Barbero, J. Oficio de cartógrafo. Santiago. F.C.E. 2002: 178 citado en Cuadra, A. 'Paisajes virtuales' (e-book) Pp.101 y ss. http://www.campus-oei.org/publicaciones.

${ }^{68}$ Garcia Canclini, Nestor. La globalización imaginada. Buenos Aires. Paidos. 1999: 98
No olvidemos que paralela a una "americanización" de América Latina se hace manifiesta una "latinización" de la cultura norteamericana. Esto que constatamos en nuestro continente habría que extenderlo a diversas culturas del planeta, fundiéndose en aquello que nombramos como cultura internacional popular o cultura global. Dos consideraciones: primera, destaquemos el papel central que le cabe a las nuevas tecnologías respecto de los fenómenos interculturales y la escasa atención que se le ha prestado a esta cuestión, tanto en el ámbito académico como político. Segunda consideración: notemos que lejos de marchar hacia la uniformización cultural a través de los mass media, como predijo Adorno, ocurre exactamente lo contrario, estamos sumidos en una cultura cuya impronta es la pluralidad.

Esta pluralidad no garantiza, necesariamente, una sociedad más democrática. Es más, se podría afirmar que la mentada multiculturalidad, construida desde los márgenes y fragmentos, es el correlato cultural del tardocapitalismo en la era de la "glocalización", desterritorializada, hipermasiva y personalizada al mismo tiempo. En pocas palabras, es la forma cultural "hipermoderna" cuya mejor garantía de sostener la adopción a nivel mundial de los flujos simbólicos, materiales y tecnológicos es, precisamente, atender a la diferencia. Como arguye Stiegler: "La modernidad, que empieza antes de la revolución industrial, pero de la que ésta es la realización histórica efectiva y masiva, designa la adopción de una nueva relación con el tiempo, el abandono del privilegio de la tradición, la definición de nuevos ritmos de vida y hoy, una inmensa conmoción de las condiciones de la vida misma, tanto en su substrato biológico como en el conjunto de sus dispositivos retencionales, lo que finalmente desemboca en una revolución indus- 
trial de la trasmisión y de las condiciones mismas de la adopción" ${ }^{69}$

La hiperindustrialización de la cultura sólo es concebible en sociedades permeables a la adopción y a la innovación permanente, esto es, sociedades sincronizadas al ritmo de la hiperproducción tecnológica y simbólica. Los vectores que materializan la adopción, y con ella la tecnología y la modernidad, son los medios de comunicación, determinados a su vez por estrategias definidas de "marketing". Ellos serán los encargados de reconfigurar la vida cotidiana a través del consumo simbólico y material, tal reconfiguración es, ahora, de suyo plural y diversa, pues :" La hegemonía cultural es innecesaria. Una vez que la elección del consumidor queda establecida como el lubricado eje del marcado en torno al cual giran la reproducción del sistema, la integración social y los mundos de la vida individuales, 'la variedad cultural, la heterogeneidad de estilos y la diferenciación de los sistemas de creencias se convierten en las condiciones de su éxito""70

En una cultura hipermoderna, cultura acelerada de flujos, la condición misma de la obra de arte radica en su hiperreproducibilidad, el arte deviene performativo. El arte se hace una "realidad de flujos" y existe en cuanto fruición en su condición exhibitiva: objeto único y al mismo tiempo hipermasivo. La nueva "aisthesis" está determinada por los modos de significación y las posibilidades expresivas del "arte virtual" en la Web, el vídeo, la televisión y el postcine. Los nuevos sistemas retencionales han transformado la experiencia y el "sensorium", poniendo en flujo nuevos sig-

\footnotetext{
${ }^{69}$ Stiegler. Op. Cit. 149

70 Bauman Z. Intimations of Postmodernity. New York/ Londres. Routledge. 1992. Citado por Lyon, D. Postmodernidad. Madrid. Alianza Editorial. 1994: 120
}

nificantes, develando la materialidad de los signos que la determinan.

La obra de arte, en cuanto hiperindustrial, establece la sincronía plena de sus flujos expresivos con los flujos de conciencia de millones de seres. En este sentido, se puede sospechar que la noción misma de "patrimonio cultural" ha sido llevada al límite, pues se trata de un patrimonio en vías de su desterritorialización y, en el límite, de su desrealización. Frente a una paisaje tal, las retóricas de museo y las bien inspiradas políticas culturales de los Estados que insisten en lo patrimonial, enmascaran las más de las veces "cartas postales" para el turismo o la propaganda. Tal ha sido la estrategia de ciudades emblemáticas devenidas iconos de la cultura, como Venecia o París. ${ }^{71}$ De hecho, Francia fue la primera nación democrática en elevar la cultura a rango ministerial en 1959, inaugurando con ello una tendencia que ha sido replicada de manera entusiasta por muchos Estados latinoamericanos como signo inequívoco de una "democracia progresista".

\section{6.- Hiperreproducibilidad: Identidad y redes}

De acuerdo a nuestra línea de pensamiento, el problema de la "hiperreproducibilidad" ocupa un lugar protagónico en la reflexión contemporánea sobre la cultura, tanto desde un punto de vista teórico comunicacional como desde un punto de vista histórico político. Como sostiene Lorenzo Vilches: " El nuevo orden social y cultural que ha comenzado a instalarse en el siglo XXI obligará a revisar las teorías de la recepción y de la mediación que ponen

\footnotetext{
${ }^{71}$ A este respecto, puede resultar ilustrativa una crítica conservadora a las políticas culturales del gobierno socialista francés en la década de los ochenta planteada por Marc Fumaroli, que en su momento resultó bastante polémica y no exenta de interés. Vease: Fumaroli, Marc. L'Etat culturel. Essai sur una religion moderne. Paris. Editions de Fallois. 1991
} 
el acento en conceptos como indentidad cultural, resistencia de los espectadores, hibridación cultural, etc. La nueva realidad de migraciones de las empresas de telecomunicaciones hacen cada vez más difícil sostener los discursos de integración de las audiencias con su realidad nacional y cultural" 72

La hiperindustria cultural entraña una "mutación antropológica" en cuanto modifica las reglas constitutivas de lo que hemos entendido por cultura. La desestabilización de los sistemas retencionales terciarios supone una transformación mayor en nuestra relación con los signos, el espacio-tiempo y toda posibilidad de representación y saber. Esto se traduce en una total reconfiguración de los modos de significación. El alcance de la mutación en curso se hace evidente si entendemos los modos de significación como correlato de la nueva economía cultural desplegada a nivel mundial. Los modos de significación aparecen, pues, sedimentados como el repertorio de los posibles histórico - perceptuales (perceptos), esto es, como un "sensorium" hipermasificado, piedra angular del imaginario social, la identidad cultural y horizonte de lo concebible.

La importancia que adquiere hoy la hiperreproducibilidad como condición de posibilidad de una hiperindustrialización de la cultura, ha tomado la forma de una lucha a nivel mundial por el control del mercado simbólico y con ello de las conciencias: "En esta nueva sociedad de la comunicación, el tiempo íntegro de los individuos para a ser objeto de comercialización... Las masas inertes, indiferentes y socialmente indefinidas del postmodernismo, emigran hacia los nuevos territorios de una sociedad que le ofrece junto con la comunicación y la información una experien-

\footnotetext{
72 Vilches. Op. Cit. 29
}

cia vital, una nueva mística de pertenencia identitaria que ni las culturas locales, ni el nacionalismo ni la religión son ya capaces de ofrecer a las nuevas generaciones"73

Es claro que la hiperindustrialización de la cultura tiende a desestabilizar las claves identitarias tradicionales. Esta tendencia debe ser, sin embargo, matizada en cuanto a que los procesos de adopción de nuevas tecnologías y los modos de significación que le son propios, no se verifican de inmediato, asemejándose más a una "revolución larga", es decir, están mediados por una suerte de "training" o aprendizaje social ${ }^{74}$. No obstante, debemos considerar que entre las condicionantes de la identidad cultural, los medios ocupan crecientemente un papel protagónico. Como explica Larraín:" El medio técnico de transmisión de formas culturales no es neutral con respecto a los contenidos. Contribuye a la fijación de significados y a su reproductibilidad ampliada, facilitando así nuevas formas de poder simbólico. Sin duda la televisión ha sido uno de los medios que más ha influido en la masificación de la cultura por el reconocido poder de penetración de las imágenes electrónicas como por la facilidad de acceso a ellas"75

Si bien debemos reconocer el papel preponderante de la televisión en la desestabilización de los anclajes identitarios tradicionales, esta tecnología mantiene todavía una distancia respecto del espectador, ofreciéndole una representación audiovisual

\footnotetext{
${ }^{73}$ Op. Cit. 57

${ }^{74}$ Benjamin , desde la dicotomía marxista clásica infraestructura-superestructura, intuye algo similar cuando escribe: "La transformación de la superestructura, que ocurre mucho más lentamente que la de la infraestructura, ha necesitado más de medio siglo para hacer vigente en todos los campos de la cultura el cambio de las condiciones de producción". Benjamin. Discursos. 18

${ }^{75}$ Larraín, Jorge. Identidad chilena. Santiago. Lom Ediciones. 2001: 242
} 
del mundo. La televisión, en tanto terminal relacional, no hace patente su materialidad tecnológica. La red IP, por el contrario, sólo es concebible como materialidad tecnológica: " Mientras la televisión lleva a los sujetos a una comprensión cultural del mundo, como lo fue la música y la literatura desde siempre, Internet y las teletecnologías conducen al desarrollo de una comprensión técnica de la realidad. Se trata de acciones técnicas que permiten la comprensión técnica de las relaciones sociales, comerciales y científicas"76

La televisión no ha tenido un desarrollo lineal y homogéneo, por el contrario, ha sido puesta alternativamente al servicio de los Estados o del mercado o de ambos. En términos generales se habla de paleotelevisión para caracterizar aquel proyecto de raigambre ilustrada en que el medio es pensado como instrumento civilizador de las masas, poniendo los canales al resguardo de universidades o del Estado mismo. La neotelevisión correspondería a la liberalización del medio, así la relación profesor / alumno es desplazada por aquella de oferentes / consumidores. Por último, en la actualidad, este medio estaría transformándose en una suerte de postelevisión en la que se abandona toda forma de dirigismo, invitando a los públicos a participar e interactuar con el medio. ${ }^{77}$

${ }^{76}$ Vilches. Op. Cit. 183

77 A la catequesis estatal o académica, siguió el estruendo publicitario de los noventa; ambos afincados en una emisión unipolar dirigista. En la era de la personalización, la interactividad toma distintas formas, pero principalmente el llamado talk - show... La promesa de la postelevisión, es la interactividad total de la mano de nuevas tecnologías. La presencia, cada vez más nítida, de lo popular interactivo en la agenda televisiva, genera todo tipo de críticas; desde la mirada aristocrática que ve en esta televisión la irrupción de lo plebeyo, hasta una mirada populista que celebra esta presencia como una verdadera democracia directa. Más allá de los prejuicios, sin embargo, queda claro que la nueva televisión interactiva está transformando no el imaginario político
Este afán mediático por integrar a sus audiencias y con ello una cierta "indistinción" entre autor y público, no es tan nuevo como se pretende, ya Benjamin advertía esta tendencia en la industria cultural pretelevisiva, concretamente en la prensa y el naciente cine ruso: "Con la creciente expansión de la prensa, que proporcionaba al público lector nuevos órganos políticos, religiosos, científicos, profesionales y locales, una parte cada vez mayor de esos lectores pasó, por de pronto ocasionalmente, del lado de los que escriben. La cosa empezó al abrirles su buzón la prensa diaria; hoy ocurre que apenas hay un europeo en curso de trabajo que no haya encontrado alguna vez ocasión de publicar una experiencia laboral, una queja, un reportaje o algo parecido. La distinción entre autores y público está por tanto a punto de perder su carácter sistemático. Se convierte en funcional y discurre de distinta manera en distintas circunstancias. El lector está siempre dispuesto a pasar a ser un escritor". ${ }^{78}$ Esta "indistinción", a la que alude Benjamin, aparece objetivada en la actualidad en la noción de "usuario", verdadero "nodo funcional" de las redes digitales. La noción de "usuario" se hace extensiva a todos los medios en la justa medida que éstos adoptan el nuevo lenguaje de equivalencia digital ${ }^{79}$.

Las imágenes audiovisuales, en parti-

de los ciudadanos sino más bien el imaginario de consumo: desde un consumidor pasivo hacia un nuevo perfil más activo. Véase: Cuadra. Op. Cit. 143

${ }^{78}$ Benjamin. Discursos. 40

${ }^{79}$ En la actualidad se observa que la red de redes esta absorbiendo los distintos medios, esto es así porque el nuevo lenguaje de equivalencia digital hace posible almacenar y trasmitir sonidos, imágenes fijas, vídeo, de tal manera que radio, prensa y televisión encuentran su lugar en los formatos de la Web. En los años venideros se puede esperar una convergencia mediática en los formatos digitales: una pantalla de plasma que permita el acceso a la red, la que incluirá todos los medios y nanomedios disponibles en tiempo real. 
cular la televisión, permiten vivir cotidianamente una cierta identidad y una legitimidad en cualquier parte, en cuanto son capaces de actualizar una memoria en el espacio virtual. Así, en cualquier lugar del mundo, un emigrante puede vivir cotidianamente una suerte de "burbuja mediática": radio, prensa y televisión, en tiempo real, en su propia lengua, referida a su lugar de origen y a sus intereses particulares, manteniendo una comuinicación íntima con su grupo de pertenencia. En suma, la experiencia de identidad ya no encuentra su arraigo imprescindible en la territorialidad. Los procesos de hiperindustrialización de la cultura implican, entre muchas otras cosas, una diseminación de las culturas locales y nuevas formas comunitarias virtuales. Sea que se trate de latinoamericanos en Nueva York, árabes en Francia o turcos en Alemania, lo cierto es que los procesos de "integración" tradicionales se encuentran con esta nueva realidad, rostro inédito de la globalización.

Si la red sirve para preservar identidades culturales fuera de la dimensión territorial, sirve al mismo tiempo para desplazar dichas identidades en un juego ficcional subjetivo. El relativo anonimato del usuario así como la sensación de ubicuidad, permiten que los sujetos empíricos construyan identidades ficticias que trasgreden no sólo el nombre propio o la identidad sexual sino cualquier otro rasgo diferenciador.

Es interesante destacar el doble movimiento que se produce en lo que podemos llamar "cultura global": por una parte, se estandariza una cultura internacional popular en un movimiento de homogeneización, por otra, se tiende a la diferenciación extrema de los consumidores. Homogeneización y diferenciación son fuerzas constitutivas del actual despliegue del tardocapitalismo en que cualquier noción de identidad ha entrado en la lógica mercantil.
Las estrategias de "marketing" construyen un imaginario variopinto que no necesita hegemonía alguna sino, por el contrario, flexibilidad que asegure los flujos de mercancías materiales y simbólicas. ${ }^{80}$

\section{7.- Fiat ars, pereat mundus}

El ensayo de Benjamin se cierra con un talante pesimista y categórico. Su condena se dirige a los postulados futuristas: "Todos los esfuerzos por un esteticismo político culminan en un solo punto. Dicho punto es la guerra. La guerra, y sólo ella, hace posible dar una meta a movimientos de masas de gran escala, conservando a la vez las condiciones heredadas de la propiedad. Así es como se formula el estado de la cuestión desde la política. Desde la técnica se formula del modo siguiente: sólo la guerra hace posible movilizar todos los medios técnicos del tiempo presente, conservando a la vez las condiciones de la propiedad". ${ }^{81}$ El contexto histórico de 1936 está signado por la aventura fascista en Etiopía y por la Guerra Civil Española, sin embargo, los fundamentos estéticos y políticos son anteriores a la Primera Guerra Mundial.

No podemos olvidar que ya en junio de 1909, F. T. Marinetti publica su Manifiesto

\footnotetext{
${ }^{80}$ Desde que T. Levitt acuñara el término globalización en 1983, se ha acelerado un proceso de recomposición mundial, en que el protagonismo de la industria manufacturera ha cedido su lugar a la industrias del conocimiento. Si el complejo militar - industrial tuvo algún sentido durante la llamada Guerra Fría, hoy es el complejo militar - mediático el nuevo nudo en torno al cual se organizan las nuevas redes que redistribuyen el poder. América Latina, en general, y Chile, en particular, han conocido ya los nuevos diseños socio - culturales neoliberales, bajo la tutela del FMI, desde hace ya más de dos décadas. Una parte central de estos nuevos diseños radica en los dispositivos comunicacionales, especialmente en la máquina mediático - publicitaria; ella es la encargada de transgredir las fronteras nacionales, violentando los espacios culturales locales. La economía global no sólo disuelve los obstáculos políticos locales sino el orden político

${ }^{81}$ Benjamin. Op. Cit. 56
} 
futurista que seducirá a muchos poetas y artistas con su llamado a la modernolatría y el nuevo y agresivo estilo fascista que glorifica la guerra: "Noi vogliamo glorificare la guerra - sola igiene del mondo - il militarismo, il patriotismo, il gesto distruttore dei libertari, le belle idee per cui si muore e il disprezzo della donna" ${ }^{2}$. El futurismo será uno de los pilares del naciente movimiento revolucionario fascista en Italia; pues junto al nacionalismo radical y al sindicalismo revolucionario en lo político, será el futurismo el que aportará un apoyo entusiasta del vanguardismo cultural de la época. ${ }^{83}$ Se puede sostener que el texto benjaminiano está estructurado sobre un doble movimiento, tanto de aperturas a nuevos conceptos, pero al mismo tiempo de clausuras, puertas expresamente cerradas a cualquier utilización política en pro del fascismo: en este sentido, estamos frente a un escrito lúcidamente antifascista.

El advenimiento de la reproducibilidad técnica aniquila lo irrepetible, masificando los objetos, transformando la experiencia humana, tal y como pensó Benjamin, haciendo posible la irrupción totalitaria: "La humanidad que antaño en Homero, era un objeto de espectáculo para los dioses olímpicos, se ha convertido ahora en espectáculo de sí misma. Su autoalienación ha alcanzado un grado que le permite vivir su propia destrucción como un goce

\footnotetext{
${ }^{82}$ Marinetti et al. Manifesto del futurismo. Firenze. Edizione Lacerba. 1914 : 6 Citado por Yurkievich. Saul. Modernidad de Apollinaire. Buenos Aires. Losada. 1968:33

${ }^{83}$ Sternhell, Z. El nacimiento de la ideología fascista. Madrid. Siglo XXI. 1994: 38 y ss

${ }^{84}$ No olvidemos que el mismo Benjamin escribe: " Los conceptos que seguidamente introducimos por vez primera en la teoría del arte se distinguen de los usuales en que resultan inútiles para los fines del fascismo. Por el contrario, son utilizables para la formación de exigencias revolucionarias en la política artística". Benjamin. Op. Cit.-18
}

estético de primer orden" 85 mismo. Nace así una estrategia que quiere alcanzar su performatividad óptima , conjugando lo global y lo local, la glocalización. En los inicios de un nuevo milenio, asistimos a la emergencia de un imperio mundial de la comunicación, que concentra, cada vez en menos manos, la propiedad de las grandes cadenas televisivas, publicitarias y de distribución cinematográfica. Véase Cuadra, A. Op. Cit. 127

Es muy interesante advertir cómo Walter Benjamin desnuda la relación entre el advenimiento del totalitarismo y la técnica como nueva forma de condicionamiento de masas: "A la reproducción masiva corresponde en efecto la reproducción de masas. La masa se mira a la cara en los grandes desfiles festivos, en las asambleas monstruos, en las enormes celebraciones deportivas y en la guerra, fenómenos todos que pasan ante la cámara. Este proceso, cuyo alcance no necesita ser subrayado, está en relación estricta con el desarrollo de la técnica reproductiva y de rodaje. Los movimientos de masas se exponen más claramente ante los aparatos que ante el ojo humano" 86 Esto es, precisamente, lo que había logrado Leni Riefenstahl en su documental de propaganda "Triumph des Willens" (E1 triunfo de la voluntad) que registró el Congreso del Partido Nazi en 1934, verdadera mise en scène para cautivar a las masas alemanas en una época pretelevisiva. Esto que es válido para las masas, lo es también para los dictadores y estrellas de cine. Como escribe Benjamin: "La radio y el cine no sólo modifican la función del actor profesional, sino que cambian también la de quienes como los gobernantes, se presentan ante sus mecanismos. Sin per-

$$
\begin{aligned}
& { }^{85} \text { Op. Cit. } 57 \\
& { }^{86} \text { Op. Cit. } 55
\end{aligned}
$$


juicio de los diversos cometidos específicos de ambos, la dirección de dicho cambio es la misma en lo que respecta al actor de cine y al gobernante. Aspira, bajo determinadas condiciones sociales, a exhibir sus actuaciones de manera más comprobable e incluso más asumible. De lo cual resulta una nueva selección, una selección ante esos aparatos, y de ella salen vencedores el dictador y la estrella de cine" 87

En la época de la hiperreproducibilidad digital, la política y la guerra posee alcances y dimensiones impensadas hace pocos años. No podemos dejar de evocar la caída de las Torres en el World Trade Center o la invasión televisada en tiempo real de países enteros, como es el caso de Irak o Afganistán. ${ }^{88}$ En la visión de Benjamin, las guerras imperialistas constituían una contradicción estructural del capitalismo: "La

$$
{ }^{87} \text { Op. Cit } 38
$$

${ }^{88}$ El desastre del World Trade Center es el resultado de un atentado terrorista de nuevo cuño, pues muestra las posibilidades inéditas de escenificar la violencia para millones de personas en el mundo. Más allá de las claras connotaciones políticas, económicas, éticas y religiosas; lo primero que salta a la vista es que la tragedia de Nueva York, y en menor escala, el ataque al Pentágono, constituye el debut del posterrorismo: un atentado mediático en red...La televisión norteamericana es, por cierto, una de las más desarrolladas y ricas del mundo. Con los recursos tecnológicos, financieros y humanos para desplegar su mirada sobre cualquier lugar del globo, es el agente ideal para poner en relato una acción de esta magnitud. Todavía permanecen frescas e inmarcesibles en la memoria las imágenes de personas lanzándose al vacío desde cientos de metros, enormes construcciones derrumbándose envueltas en llamas y cientos de personas corriendo desesperadas por las calles. La televisión administra la visibilidad, pues junto a aquello que se nos muestra, se nos oculta.: tras los primeros momentos de estupefacción, la mirada televisiva comienza a ser regulada. La construcción del relato televisivo depende estrictamente de la administración de su flujo de imágenes. El continuum televisivo construye así un transcontexto virtual mediático en que la historia con su carga de infamias y violencia es sustituida por un espacio acrónico metahistórico que se resuelve en un presente perpetuo de héroes y villanos. Véase: Cuadra, A. 'Paisajes virtuales' (e-book) Pp.68 y ss. http://www.campus-oei.org/ publicaciones guerra imperialista está determinada en sus rasgos atroces por la discrepancia entre los poderosos medios de producción y su aprovechamiento insuficiente en el proceso productivo (con otras palabras: por el paro laboral y la falta de mercados de consumo). La guerra imperialista es un levantamiento de la técnica, que se cobra en el material humano las exigencias a las que la sociedad ha sustraído su material natural. En lugar de canalizar ríos, dirige la corriente humana al lecho de sus trincheras; en lugar de esparcir grano desde sus aeroplanos, esparce bombas incendiarias sobre las ciudades; y la guerra de gases ha encontrado un medio nuevo para acabar con el aura"89.

La humanidad contemporánea vive su propia destrucción - y la del planeta que la acoge - ya no como un goce meramente estético, como pensó Benjamin, sino como un tecno - espectáculo, en que el virtuosismo de la tecnología se funde a la pasión irracional y nihilista. El despliegue del tardocapitalismo hipermoderno desplaza la cultura más allá del Bien y del Mal, y en una lectura heterodoxa y extrema, habría que consentir con Baudrillard cuando escribe: "No hay principio de realidad ni de placer. Sólo hay un principio final de reconciliación y un principio infinito del $\mathrm{Mal}$ y de la seducción" $"$. La figura prototípica que nos propone este pensador hipermoderno es Ubu, el célebre personaje patafísico $^{91}$ de Alfred Jarry: "Cualquier tensión

\footnotetext{
${ }^{89}$ Benjamin, Discursos. 57

${ }^{90}$ Baudrillard, Jean. Las estrategias fatales. Barcelona. Editorial Anagrama. 6o Edición. 2000: 76

${ }^{91}$ La patafísica es una parodia de la metafísica aristotélica, acaso un primer intento postmetafísico ; se trata de una forma peculiar de razonamiento basado en soluciones imaginarias que disuelve las categorías lógicas al uso, cuya proposición es una reconstrucción en un ars combinatoria en que prima lo insólito. Thomas Scheerer resume en siete tesis fundamentales el pensamiento patafísico; tomadas del libro
}

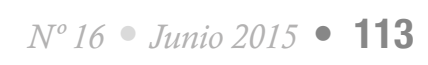


metafísica se ha disipado, siendo sustituida por un ambiente patafísico, es decir, por la perfección tautológica y grotesca de los procesos de verdad. Ubú: el intestino delgado y el esplendor de lo vacío. Ubú, forma plena y obesa, de una inmanencia grotesca, de una verdad deslumbrante, figura genial, repleta, de lo que ha absorbido todo, transgredido todo, y brilla en el vacío como una solución imaginaria" 92 Si bien, a primera vista, se trata de una filosofía "cínica", habría que considerar lo que aclara el mismo Baudrillard: “...no es un punto de vista filosófico cínico, es un punto de vista objetivo de las sociedades, y acaso de todos los sistemas. La propia energía del pensamiento es cínica e inmoral: ningún pensador que sólo obedezca a la lógica de sus conceptos jamás ha llegado a ver más lejos de sus narices. Hay que ser cínico si no se quiere perecer, y esto, si se me permite decirlo, no es inmoral: es el cinismo del orden secreto de las cosas"93

Jarry, un outsider, dio un paso decisivo hacia la nueva conciencia poética que cristalizará años más tarde con Apollinaire y Tristan Tzara. Sin embargo, la "pataphysique" 94 también nos prefigura una de las

de Roger Shattuch, Au seuil de la pataphysique (1950), texto doctrinal del Collège de pataphysique: Véase: Scheerer, T. Introducción a la patafísica in Revista Chilena de Literatura Santiago. No 29. 1987: 81 - 96

92 Baudrillard. Op. Cit. 76

${ }^{93}$ Op. Cit 76

${ }^{94}$ La "pataphysique" contiene el germen de lo que será una nueva estética, la estética de la obra abierta, del texto plural presidido por el juego, el humor y lo absurdo: pensemos en el desarrollo de todo el repertorio verbo icónico de los comics y, hoy en día, toda una nueva generación de cartoons y series como los Simpsons o los gags de MTV, para no mencionar los muchos spots publicitarios que nos asedian día a día por televisión. Esto ha sido captado con maestría por el escultor colombiano Ospine, quien es capaz de recrear los iconos de la cultura de masas a partir de los estilemas de culturas prehispánicas.

$114 \cdot$ Junio $2015 \bullet N^{o} 16$ miradas actuales en torno a lo social, sea que la llamemos postmoderna o hipermoderna $^{95}$, aquella, precisamente, que proclama el festín sígnico de la cultura contemporánea: "No es nunca el Bien ni lo Bueno, sea éste el ideal y platónico de la moral, o el pragmático y objetivo de la ciencia y de la técnica, quienes dirigen el cambio o la vitalidad de una sociedad; la impulsión motora procede del libertinaje, sea éste el de las imágenes, de las ideas o de los signos"96

Más allá de las ingenuas desideratas y de algunas visiones cínicas o apocalípticas, resulta claro que asistimos a la emergencia de un nuevo diseño sociocultural, cuyos ejes son la hipermediatización y la virtualización. Para gran parte de la población actual, sus patrones culturales, sus claves identitarias y sus experiencias cotidianas con la realidad ha sido configurada y se nutre de la hiperindustria cultural. Este es el ámbito en que se construye la historia y el sentido de la vida para la gran mayoría, plasma digital donde se escenifican los abismos y horrores de la hipermodernidad.

La violencia y lo hórrido tratados con una ascesis hiperobjetivista nos ofrece el vértigo y la seducción de la guerra sentados en primera fila. Nada parece suficiente para conmover a las audiencias hipermasivas. Estamos lejos de aquel reclamo benjaminiano que suponía unas masas anhelantes de suprimir las condiciones de propiedad ${ }^{97}$, ni regresión a ideologías duras ni militancias revolucionarias. En cambio, constata-

\footnotetext{
${ }^{95}$ Para un diagnóstico próximo a nuestra línea de pensamiento en cuanto a una modernización de la modernidad, véase: Lipovetsky, G. Les temps hypermodernes. Paris. B. Grasset. 2004

${ }^{96}$ Baudrillard. Op. Cit. 77

${ }^{97}$ Escribe Benjamin: "El fascismo intenta organizar las masas recientemente proletarizadas sin tocar las condiciones de la propiedad que dichas masas urgen por suprimir" Benjamin. Discursos. 55
} 
mos la consagración plena del consumo y las imágenes, en la materialidad de los significantes, desprovistos de su connotación histórica y política, que nos muestran día a día la obscenidad brutal de la destrucción y la muerte.

Todo reclamo humanista es observado con indiferencia y, en el mejor de los casos, con distancia y escepticismo. En la época hipermoderna se impone la búsqueda del efecto. En un universo performativo, todo discurso ha sido degradado a la condición de coartada. Cuando las instancias de legitimidad se desdibujan, sólo la acción performativa es capaz de generar su "ersatz": un atentado, un magnicidio, un genocidio, una guerra.

Ante el sentimiento de catástrofe con que se inaugura el presente siglo, ya nadie espera el advenimiento de alguna utopía religiosa o laica: "La teoría crítica de comienzos del siglo $\mathrm{XX}$, y los movimientos sociales de signo socialista $y$ anarquista, veían en la acumulación creciente de fenómenos negativos de nuestra civilización, desde el empobrecimiento económico de la sociedad civil hasta la degradación estética de las formas de vida, el signo de un límite a la vez espiritual e histórico de la sociedad industrial. Un límite histórico o una crisis llamados a revelar un nuevo orden a partir de lo viejo. Semejante perspectiva revolucionaria ha sido eliminada enteramente de nuestra visión del futuro a comienzos del siglo XXI" "El ethos hipermoderno ha asimilado su " condición histórica negativa" 99 y se ha enclaustrado en la pura performatividad, alcanzando así una cierta inmunidad frente a las profecías del fin de los tiempos, sean éstas de inspiración apocalíptica o dialéctica.

\footnotetext{
${ }^{98}$ Subirats. Op. Cit. 15

${ }^{99}$ Op. Cit. 16
}

A más de medio siglo de distancia, la crítica contemporánea a Benjamin, se divide, según algunos en "comentaristas" y "partidarios": "Hoy, las lecturas de Benjamin se dividen en dos grandes grupos, cuyos nombres pongo entre comillas: los 'comentaristas' y los 'partidarios'. Para decirlo de modo menos enigmático: quienes piensan a Benjamin fundamentalmente en relación con una tradición filosófica o crítica; y quienes lo piensan como filósofo de ruptura... Las cosas no son sencillas, pero debería agregar que los 'comentaristas' no pasan por alto la ruptura introducida por Benjamin en el marco de la tradición: y los 'partidarios', a su vez, reconocen la tradición pero establecen con Benjamin un dialogo fundado en el presente" 100

Más allá de la tipología propuesta, habría que subrayar que el interés actual por Walter Benjamin sólo prueba la fecundidad de su pensamiento, convertido en referencia obligada en cualquier reflexión consistente sobre la cultura contemporánea. Así, Bernard Stiegler va a criticar a los frankfurtianos en los siguientes términos: “ $\mathrm{Su}$ fracaso consiste en no haber comprendido que si es cierto que la composición de las retenciones primarias y secundarias, que constituye el verdadero fenómeno del objeto temporal y que explica que el mismo objeto repetido dos veces pueda dar dos fenómenos diferentes, si, por lo tanto, es cierto que esta composición está sobredeterminada por las retenciones terciarias en sus características técnicas y epokhales, el centro de la cuestión de las industrias culturales es entonces que éstas constituyen una realización industrial $\mathrm{y}$, por lo tanto, sistemática de nuevas tecnologías de las retenciones terciariasy, a través de ellas, de criterios de selección de un nuevo tipo - y,

${ }^{100}$ Sarlo. Op. Cit 72 
en este caso, sometido totalmente a la lógica de los mercados.." ${ }^{101}$. Sin embargo, para poner la reflexión en cierta perspectiva histórica, habría que señalar que ninguno de los pensadores frankfurtianos pudo siquiera imaginar una producción tecnocientífica total de la realidad como acontece con los flujos hiperindustriales, por lo mismo, esto marca uno de sus límites, como muy bien nos advierte Subirats: "La limitación histórica verdaderamente relevante del análisis de los medios de reproducción y comunicación de Horkheimer y Adorno, así como de Benjamin, reside más bien en el hecho de omitir lo que hoy podemos contemplar como la última consecuencia de su desarrollo: la transformación entera de la constitución subjetiva del humano allí donde sus tareas de apercepción, experiencia e interpretación de la realidad le son arrebatadas y suplantadas enteramente por la producción técnica masiva de la realidad misma" ${ }^{102}$

\section{8.- Epílogo}

Al instalar la noción benjaminiana de "reproducibilidad" de la obra de arte en el centro de una reflexión para comprender el presente, emerge un horizonte de comprensión que nos muestra los abismos de una "mutación antropológica" en la que estamos inmersos. Asistimos, en efecto, a una transformación radical de nuestro "régimen de significación": El actual desarrollo tecnocientifico, materializado en la convergencia de redes informáticas, de telecomunicaciones y lenguajes audiovisuales ha hecho posible un nuevo nivel de reproducibilidad tanto en lo cualitativo como en lo cuantitativo, a esto hemos llamado:

\footnotetext{
101 Stiegler. Op. Cit. 61

102 Subirats, E. Culturas virtuales. Madrid. Biblioteca Nueva. 2001: 14
}

$116 \bullet$ Junio $2015 \bullet N^{o} 16$ "hiperreproducibilidad". Esto ha permitido la expansión de una "hiperindustria cultural", red de flujos planetarios por los cuales circula toda producción simbólica que construye el imaginario de la sociedad global contemporánea.

El nuevo "régimen de significación" se materializa, desde luego, en una economía cultural cuyos centros de producción y distribución se encuentran en el mundo desarrollado, pero cuyas terminales de consumo despliegan su capilaridad por todo el planeta. Al mismo tiempo y junto a esta nueva economía cultural, se está produciendo una soterrada revolución, sin precedentes, un cambio en los "modos de significación". Un nuevo lenguaje de equivalencia digital absorbe y reconfigura los sistemas de retención terciarios, convirtiéndose en la mnemotecnología del mañana. La "hiperindustrialización de la cultura" no sólo es la nueva arquitectura de los signos sino del espacio tiempo y de cualquier posibilidad de representación y saber.

Los nuevos modos de significación constituyen, en el límite, una nueva experiencia. Se trata, por cierto, de una construcción histórico cultural fundamentada en la percepción sensorial, pero cuyo alcance en los procesos cognitivos y en la constitución del imaginario redundan en un nuevo modo de ser. Las nuevas tecnologías son, de hecho, la condición de posibilidad, de esta experiencia inédita de ser, sea que la llamemos "shock" o "extasis", y han alterado radicalmente nuestro Lebenswelt. Esta nueva organización de la percepción sólo es comprensible, como nos enseñó Benjamin, en relación a grandes espacios históricos y a sus contextos tecnoeconómicos y políticos.

Este nuevo estadio de la cultura confiere a la obra de arte en la época hipermoderna, y con ella a toda la producción simbólica, la condición de presentificación ontológicamente sustantivada, plena y efímera. La 
obra de arte se transforma en un "objeto temporal", flujo hipermedíatico sincronizado con flujos de millones de conciencias. La nueva arquitectura cultural, como esas imágenes de Escher, se nos ofrece como un "presente perpetuo" en que percibimos los relámpagos de las redes y laberintos virtuales. Son las imágenes que nos seducen cotidianamente, aquellas que constituyen nuestra propia memoria $\mathrm{y}$, más radicalmente, nuestra propia subjetividad. Una manera, oblicua e inacabada si se quiere, de evidenciar que la heurística inaugurada por Walter Benjamin es susceptible de lecturas contemporáneas, precisamente, cuando la reproducibilidad técnica ha devenido hiperreproducibilidad digital. 